\title{
مُتَّطلبات تطبيق القيادة التوزيعية بمؤسسات رياض الأطفال في ضوء بعض الاتجاهات المعاصرة
}

\author{
إعـداد \\ د. أحمد محمد ابراهيم هميسة \\ مدرس ادارة رياض ألأطفال \\ كلية رياض ألأطفال- جامعة الفيوم \\ DOI: $10.12816 / 0045606$
}

مجلة الدراسات التربوية والانسانية ـ كلية التربية ـ جامعة دمنهور . المجلد الثامن - العدد الثالث - لسنة 2016 
منطلبات تطبيق القيادة التوزيعية بمؤسسات رياض الأطفال فى ضوء بعض الاتجاهات د. أحمد محمد هيسة 
مجلة الدراسات التربوية والانسانية ـ كلية التربية ـ جامعة دمنهور المجلد الثامن - العدد(3)- لسنة 2016 
منطلبات تطبيق القيادة التوزيعية بمؤسسات رياض الأطفال فى ضوء بعض الاتجاهات د. أحمد محمد هيسة متطلبات تطبيق القيادة التوزيعية بمؤسسات رياض الأطفال في ضوء بعض الاتجاهات المعاصرة

\section{د. أحمد محمد هميسة}

\section{DOI: 10.12816/0045606}

\section{مقدمة}

أصبحت سمه العصر الذى نعيشـهـ الأن هو التغيير المستمر ، حيث نسوده العديد من المتغيرات المتصارعه التى تضع المنظمات بصفه عامه والتربويه منها بصفه خاصسه أمام تحديات تجعلها تعمل جاهده على استثمار جهودها لتحقيق لصن أهدافها من خلال إداره ناجحه.

لذلك وجب عليها العمل على رفع كفاءه إدارتها وترشبد قياداتها،ونظراً لأن القياده بالنسبـه للمنظمـة هـى بمثابـه المدخل الحقيقى لتحقيق نجاحاتها وتميزهـا

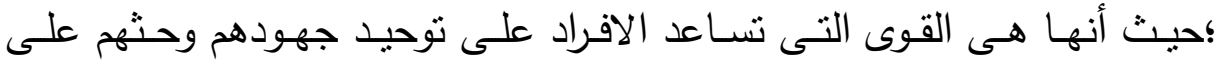
التغيير ؛ فقد إرتبط مدى نجاح اى منظمه بمقدار تمتعها بقياده ناجحه وفعاله.

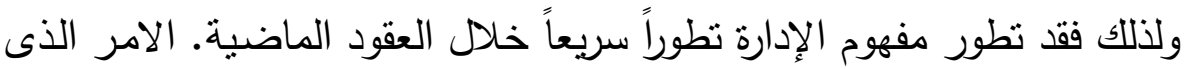
انعكس بدوره على الإدارة المدرسية؛ مما أدى إلى تعقد الدور الذي يقوم بـه مدير

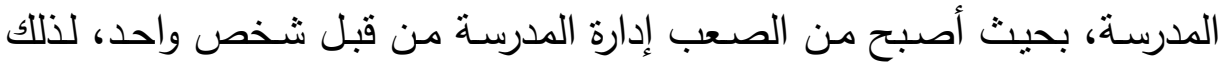

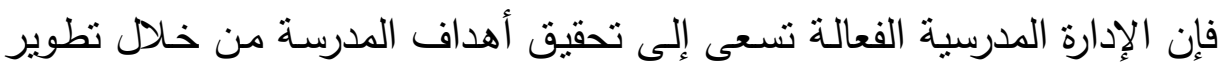
نظمها والمهام الوظيفية (الممارسات) التى يقوم بها مديري المدارس (1).

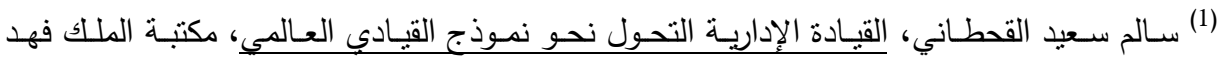

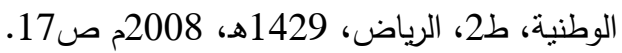


ويتوقف نجاح الإدارة المدرسية في تحقيق أهدافها بكفاءة وفعالية على نمط

القيـادة التـي تعتبـر مـن أهـ عناصـرها بـل تعتبـر الركيـزة الأولى في في العمليـة

$$
\text { الإدارية (2) }
$$

ومؤسسات رياض الأطفال في ظل قيادات الوضـع الراهن بحاجـة إلى تعديل من الروتين الكائن بها إلى الإبداع والتجديد في توظيف المداخل القيادية الحديثة،

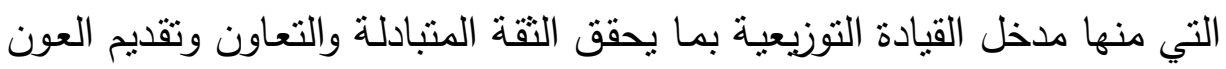

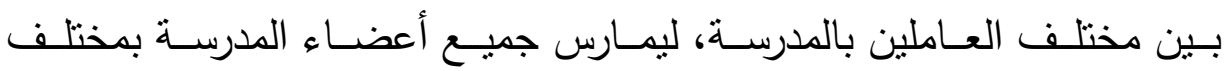

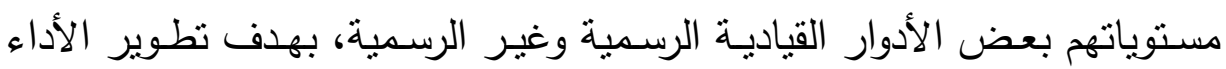

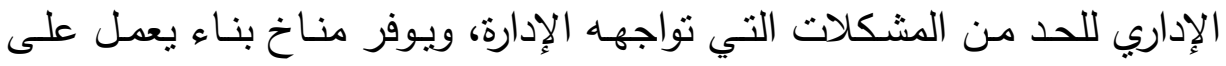
تفجير الطاقات الإبداعية للمعلمين مع إمكانية أن يقوموا بأدوار قيادية والمشاركة

في عملية صنع القرار (3). وتعتبر القيادة التوزيعية (Distributed Leadership) أحد أثكال القيادة التي يمكن أن تساهم بفعالية في التصدي للتحديات الكبيرة التي تواجه المديرين، فضــا عـن مسـاهمتها الرئيسية في تحسـين وتطـوير المنظمـات بصـفة عامـة

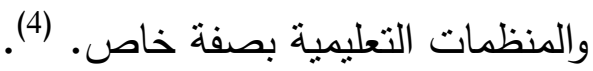
وتعتمـد القيادة التوزيعيـة على مشـاركة المعلم في القيادة على الانتقال مـن

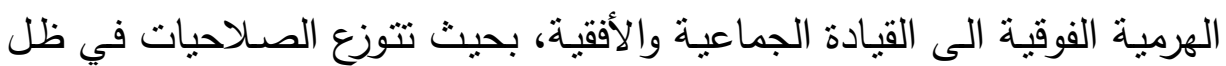

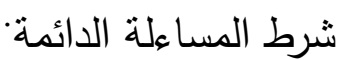

(2) Elmore, R \& Building a New structure for school leadership. Washington, DC: the Albert shanker Institute,2000, P5. (3) رافدة عمر الحريري، ، القيادات الإدارية لمدارس المستقبل في ضوء الجودة الثاملة، عمان، الأردن،

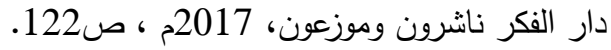

(4) Warfield, C. A Social Network Analysis of Distributed Leadership in Schools, Unpublished doctoral dissertation, University of Pennsylvania, Philadelphia, USA, 2009, P.22. 
إن مشـاركة المعلم في عملية القيادة ومعاونته لفريق الإدارة في تحقيق أهداف المؤسسـة، وذلك فيمـا بنطوي عليـه مفهوم القيـادة التوزبعيـة، يـؤدي الى تحسين وتطوير الأداء الإداري في تطبيق القيادة التوزبعية بمؤسسات رياض الأطفال في ضوء بعض الاتجاهات المعاصرة؛ ولذلك لأنه يسـاعد على التغلب على العديد من المشكلات التي تواجهها الإدارة. حيث أكدت نتائج العديد من الدراسـات احتكار مدير المدرسـة لعمليـة اتخـاذ القرارات الإداريـة كما أكدت أيضـاً أن مشـاركة المعلم في عملية اتخـاذ القرارات الإدارية تُعد ضعيفة. (5). وبمـا أن الإدارة المدرسية هي المـدخل إلى تطـير وتجديد التعليم في سبيل تحقيق أهدافه، وهـي تطوبر المجتمـع وتتميته الثـاملة، فـان الحاجـة ملحـة الآن للتحول الجذري مـن الأنماط الإداريـة التقليديـة إلى أنماط جديدة تتسـم بالمرونـة والتعـاون وتقوم على أسـاس المشـاركة، وذلك مسن خـلال تطبيـق مـدخل الإدارة القائمة على القيادة التوزيعية (6). وبرى الباحث أنه على الرغم من المحاولات المستمرة لتطوير الأداء الإدارى بمؤسسـات ريـاض الأطفـال بمـا يجعلهـا قـادرة على مواجهـة تحـديات العصـر

1-ناعم أحمد سلطان العرري، ، واقع مشاركة معلمي المررطة الثانوية بدينة الرياض في عملية انخاذ القرارات الددرسية دراسة ميدانية في

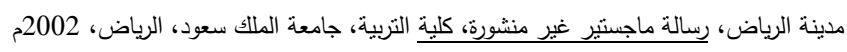
2-عبداله بالقاسم عبداله البكري، ، واقع ممارسة مديري الددار تفويض الصلاحيات للمعلمين وعلاقته بتحقيق فعالية الددرسة دراسة ميدانية في محافظة النماص، رسالة ماجستير غير منشورة، جامعة الملك خالد، أبها، 1426هـ 3-على سويلم حسن الصغير ، ، واقع تفويض الصلاحيات لاى مديري المدارس الثانوية بمدينة الرياض، رسالة ماجستير غير منشورة، كلية التربية، جامعة الملك سعود، الرياض، 14277هـ (1) رافدة عمر الحريري، مرجع سابق، 2017م ، ص45. 
والاستجابة لمتطلبات التطوير التربوى، إلا أن الدراسات التى تمت فى هذا المجال

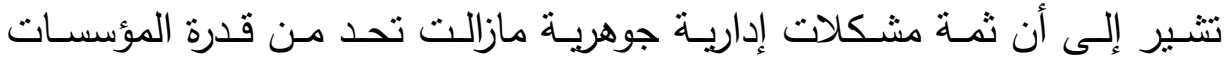

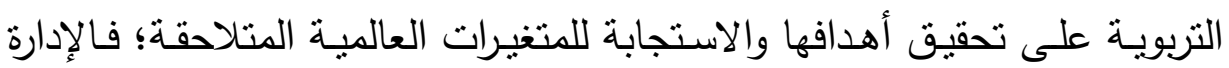
التربوية فى مصر تعانى من انعدام الرقابة على التعليم مـع ما يتضمنه ذللك من النه

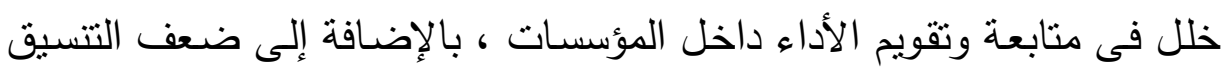

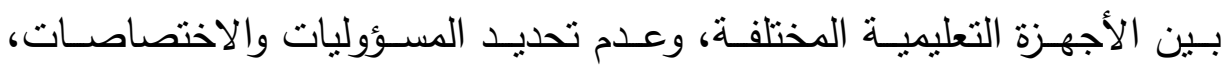
ودكتانورية صنع واتخاذ القرارات التربوية، وعدم التوازن بين المهام الفنبة والمهام الإدارية للقيادات المدرسية، والأساليب التقليدية فى تقلد المناصب الإدارية.

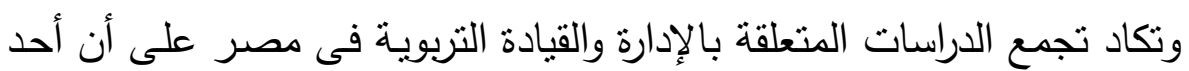

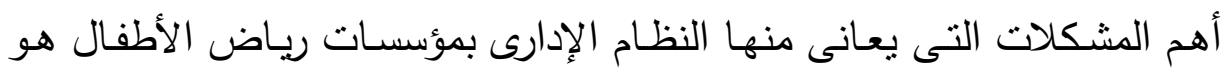

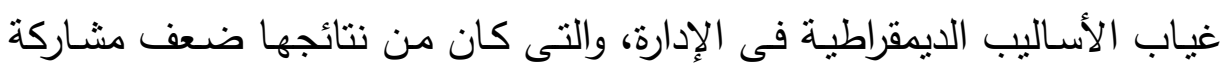

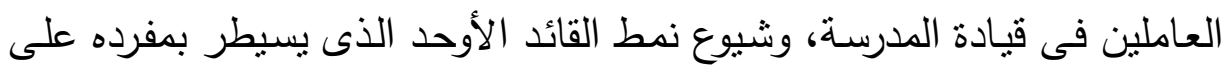

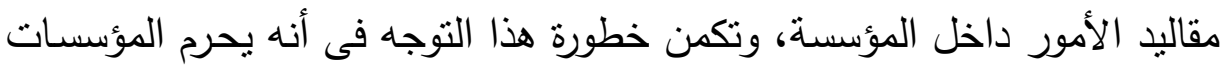

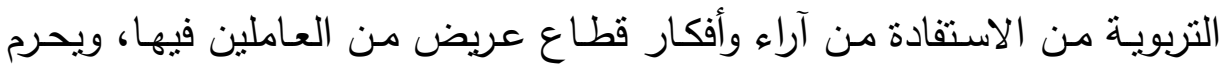
هؤلاء العـاملين مـن ممارسـة حقهم فى الإسـهام فى تطوير مدارسـهم وصـياغة رؤيتها للمستقبل.

ويعتقد الباحث أن شيوع هذا النمط من القيادة يمثل إنثكالية كبيرة، وخاصـة إذا

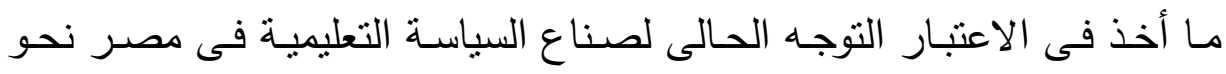

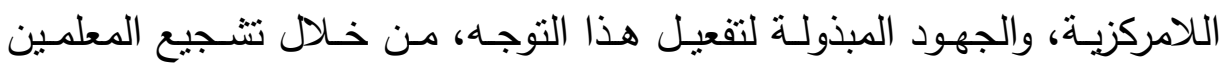
والإداريين وأعضاء المجتمع المحلى على المشاركة فى قيادة مدارسهم والإسهام فى حل مشكلاتها، لذلك وجب على المنظرين والباحثين فى ميدان الإدارة التربوية

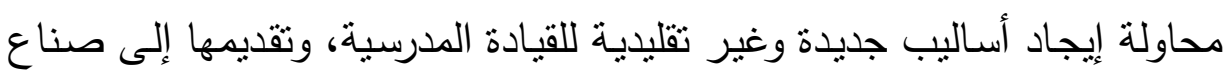


منطبات تطبيق القيادة التوزيعية بمؤسسات رياض الأطفال فى ضوء بعض الاتجاهات ـ. أحمد محمد هميسة

السياسـة التربوبـة كمقترحسات لتفعيـل اللادركزيـة وديمقراطيـة القيـادة فـى الواقع

(7) التعليمي

لذلك تعتبر القيادة التوزبعيـة أحد هذه الأسـاليب الديمقراطيـة فى القيادة على

اعتبـار أنها تتضـمن إعـادة توزيـع السـلطة والمهـام القياديـة داخل المؤسسـة بمـا

يضمن مشاركة أكبر عدد مدكن من أعضـاء المجتمع المدرسى فى القيادة، إلا

أنه رغم الحظوة التى اكتسبها هذا المفهوم فى السياقات التربوبة الغربية التى نشـأ فيها، فإنـه لم يحظ بالقدر الكافي من الاهتمـام من قبل الباحثين العرب عموما، وفى السياق التربوى المصرى على وجه الخصوص. ومن هنا فإن مشكلة البحث الحالي تتمثل في الأسئلة التالية:

س 1: ما واقع ممارسة القيادة التوزيعية لاى مديري مؤسسات ريـاض الأطفال بمصر

س2: ما معوقات ممارسة القيادة التوزيعية بمؤسسات رياض الأطفال بمصر؟ س 3: ما متطلبات ممارسة القيادة التوزيعية بمؤسسات رياض الأطفال بمصر؟ • حدود البحث :

تتحدد البحث بالحدود التالية:

ـ الحدود الموضوعية

اقتصر موضوع البحث الحالي على (تطوير واقع ممارسـة مديري مؤسسات رياض الأطفال بمصر للقيادة التوزيعية) من خلال التعرف على معوقات ومتطلبات ممارسة

القيادة التوزبعبة.

: (2)

1-ناعم أحمد سلطان العمري، مرجع سابق.

2-عبداله بالقاسم عبداله البكري، مرجع سابق.

DOI: $10.12816 / 0045606$

178 


\section{الحدود المكانية}

اقتصرت البحث الحالي على مؤسسات رياض الأطفال بمحافظة كفرالثيخ. • الحدود البشرية الحت الحية

$$
\begin{aligned}
& \text { اقتصرت البحث على مديري المدارس ووكلاء ومعلمات أوائل. } \\
& \text { • الحدود الزمانية } \\
& \text { الفصل الأول من العام الدراسي 2016-2107م. }
\end{aligned}
$$

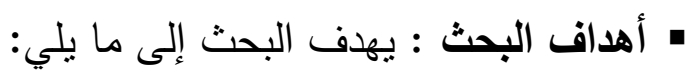

- رصد واقع ممارسـة القيادة التوزيعية لاى مديري مؤسسـات رياض الأطفال

$$
\text { بمصر }
$$

- التعرف على معوقات ممارسـة القيادة التوزيعية بمؤسسـات رياض الأطفال بمصر .

- وصف وتحليل متطلبات ممارسة القيادة التوزيعية بمؤسسات رياض الأطفال

$$
\text { • أهمية البحث: }
$$

تتمثل أهمية البحث الحالي في النقاط الآتية:

1- يعد البحث الحالي - على حد علم الباحث- من الدراسـات القلائل التي لئي

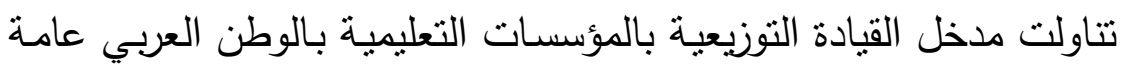

$$
\text { ومصر خاصة. }
$$

2- قد تساهم نتائج البحث الحالي المسؤولين بوزارة التربية والتعليم من واضعي السياسـات ومتخذي القرارات على التعرف على متطلبات تطبيق القيادة التوزيعية بمؤسسات رياض الأطفال، إذا ما رغبت الوزارة في تطبيق هذات

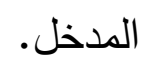


3- قد يسـاعد البحث الحالي في تحسين وتطوير أداء إدارة المدرسـة الثانويـة

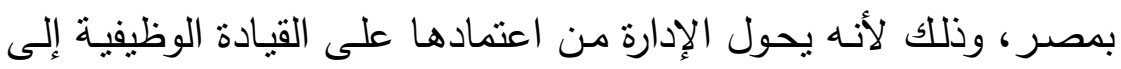

اعنمادها على القيادة التوزيعية.

4- يمكن الاستفادة من نتائج البحث في تعديل الممارسات والسلوكيات التي

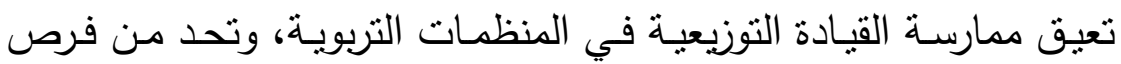
التجديد والابتكار عن طريق تشجيع المشاركة في اتخاذ القرارات، وإتاحة

الفرصة للعاملين في إبداء تصوراتهم حول تطوير العمل.

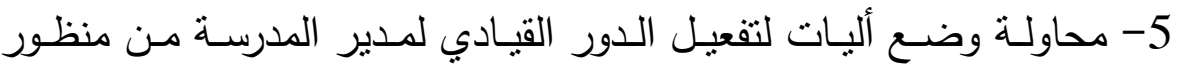

القيادة التوزيعية.

6- تعد من أوائل الدراسات فى مصر التى نتتاول مفهوم القيادة التوزيعية، لذا

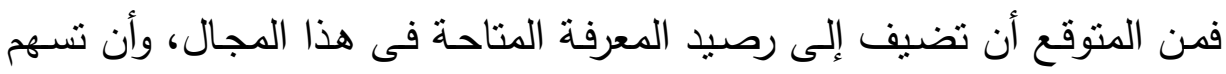

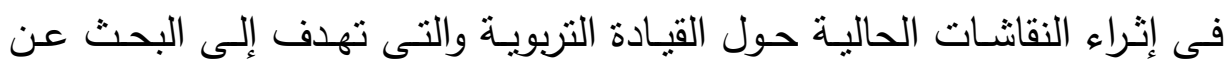

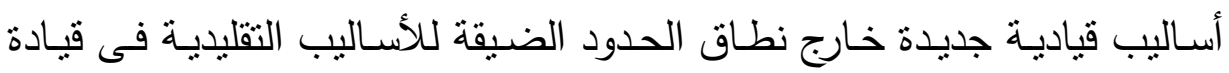
المؤسسات التزبوية.

7- الدراسة منسقة مع التوجه الحالى لصانعى السياسة التربوية فى مصر نحو

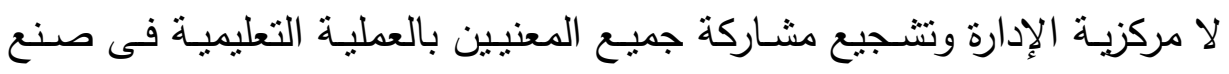

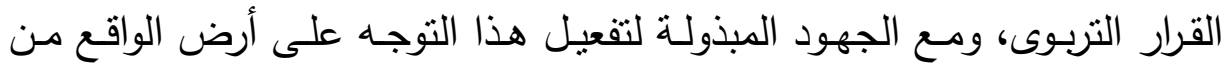

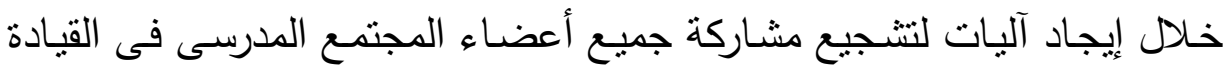

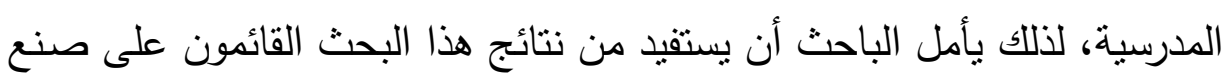

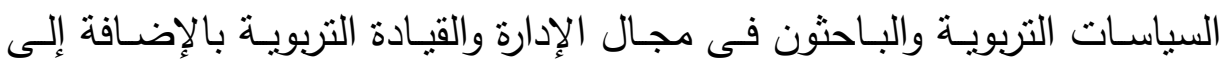
ممارسى القيادة التزبوية على جميع المستويات. 
بـالرغم من عدم وجود دراسـات موجهة بشكل خاص لاستقصساء واقع القيادة التوزيعيـة فى السياق التربوى المصـرى، إلا أن ميدان البحث في مجى مجال الإدارة

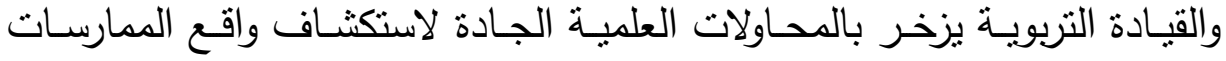

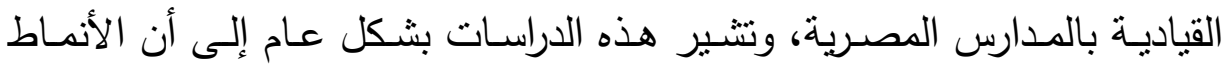
القيادية التقليدية مازالت سائدة فى المؤسسات التربوية على اختلاف مستوياتها؛ فمركزية القرارات التربوية، والاهتمام بالأساليب على حساب العاملين، والخلط بين مفاهيم الولاء الثخصسى والولاء المؤسسى، وتعدد أجهزة الرقابـة والمتابعـة كلها

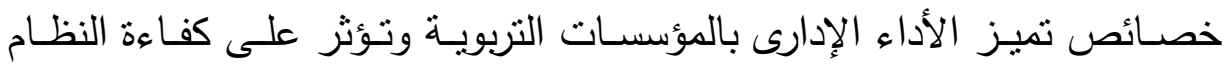

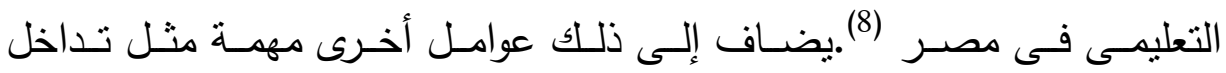
الاختصاصـات وحدوث صـراع الأدوار، وعدم التوازن بـين متطلبـات التطـوير

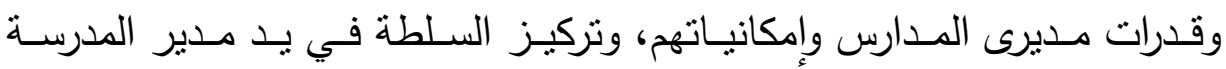
والتطبيـق الحرفي للـوائح والقـوانين، وضــف الصــلاحيات المنوحــة لــلإدارة المدرسية)

ومن بين المعوقات العديدة التى تعانى منها الإدارة المدرسية فى مصر ، برزت

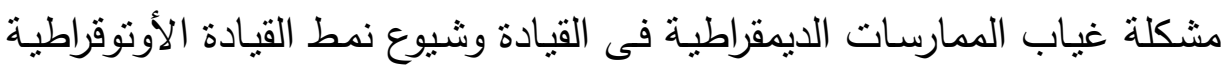
كإحدى المشكلات التى نالت قسطا كبيرا من اهتمام الباحثين فى مجال الإدارة

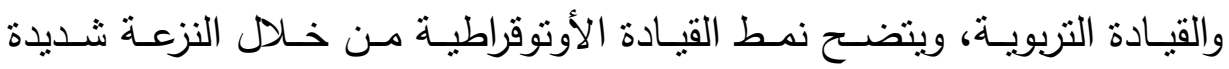

(1) محمد جودة التهامى، (2010). أنماط الإدارة التعليمية المتبعة فى بعض الدول وانعكاساتها

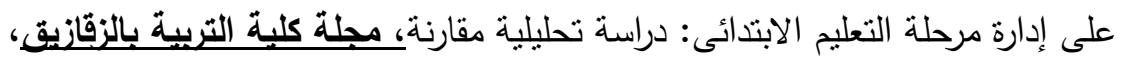

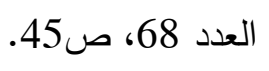

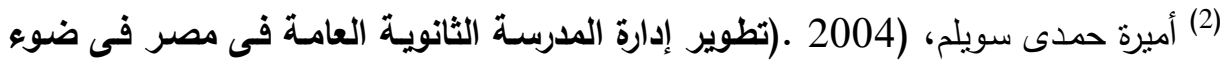

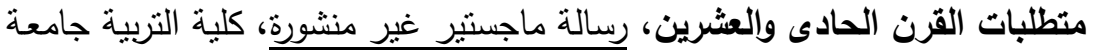
الزقازيق، صوبات 
المركزية فى إدارة المدرسة والتى تتمثل فى تركيز السلطة فى يد من هم على قمـة

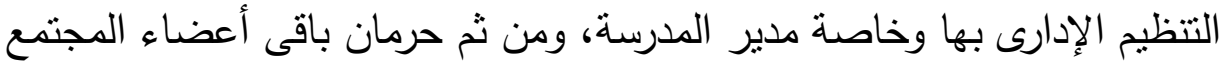
المدرسى من المشاركة فى قيادة المؤسسة، وتعتبر تللك إحدى المشكلات المزمنـة

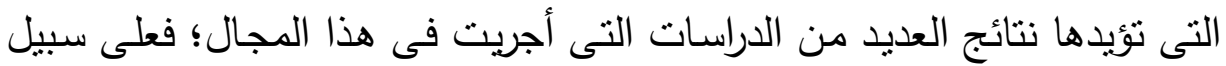

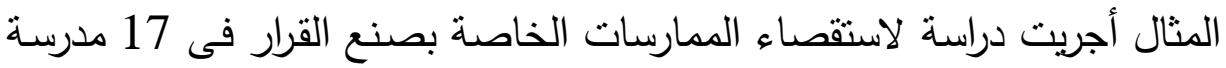
ثانوية عامة فى محافظة الدقهلية، وقد أظهرت النتائج أن معظم المدراء استخدموات لاهياء

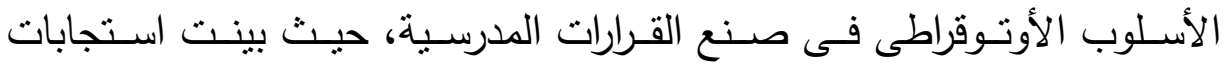
المعلمين أن المدراء لم يشركوهم فى صنع القرارات ولم يسعوا حتى لكسب تأييدهم

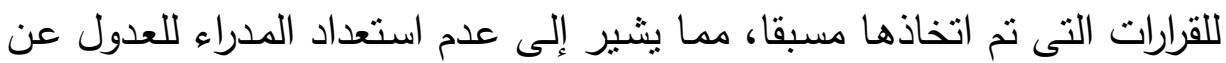
هذه القرارات حتى وإن كانت غير صائبة (10).

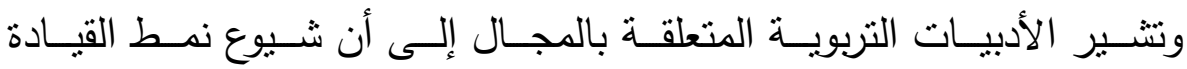

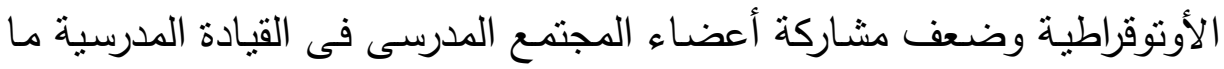

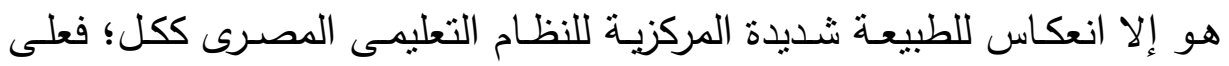
الرغم من المحاولات العديدة والجهود التى بذلت من قبل الوزارة لتفعيل اللامركزية

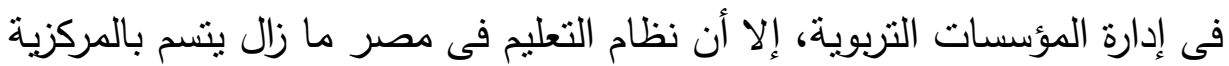

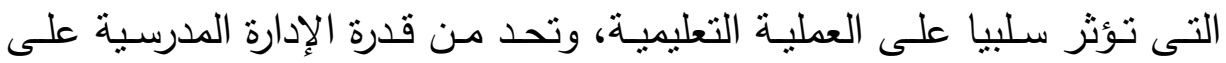
الإبـداع ومـن ثم تعـوق أفرادهـا عن تحقيـق التجديد الـذاتى ومواكبـة النطـورات المتلاحقة التى يتسم بها عالم اليوم (11).

(1) حميدة محمود عطا اله، (199).(لجهودة التعليمية وانعكاسـاتها على إدارة الاجتماعـات

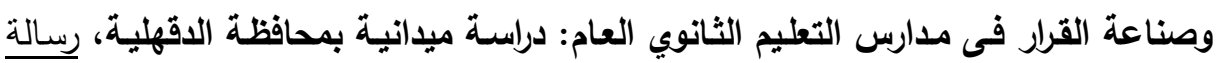
ماجستير غير منشورة، كلية التربية جامعة المنصورة.

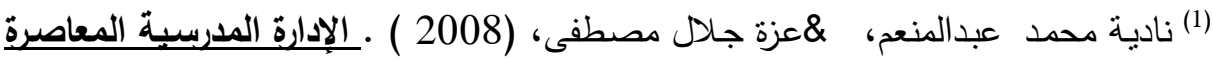

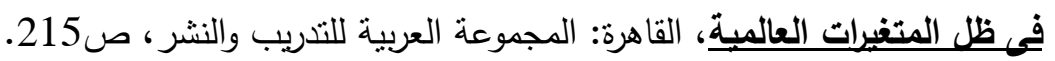
DOI: $10.12816 / 0045606$ 
ومن بين العوامل التى تسهم فى تشكيل أنماط القيادة التربويـة فى المدارس المصرية هو تقييد مدير المدرسـة بـاللوائح والقوانين والنشـرات والقرارات الوزاريـة التى تنظم العمل داخل مدرسته، مما يتتافى مع المرونـة والديناميكية التى يجب لهب أن يتسم بها العمل المدرسى، ويضيف مصطفى أنه عندما يتم تقييد حرية المدير فى التخطبط لنمو العمل فى مدرسته ومتابعته وتقويمه، فإن الدور القيادى لمدير

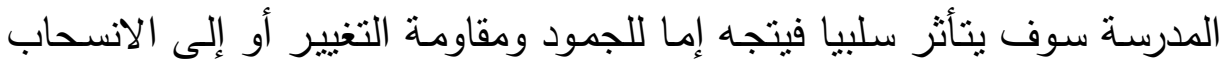
والسلبية(12).

وثمـة دراسـات تؤكدبشكل عملى على العلاقـة بين الطبيعـة المركزيـة للنظـام

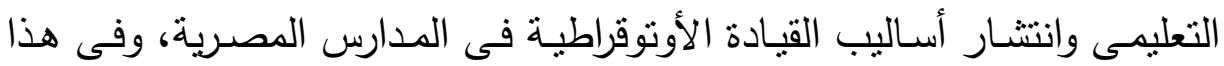
الصدد يشير الباحثان على سبيل المثال إلى دراسة حماد ونوريس Hammad)

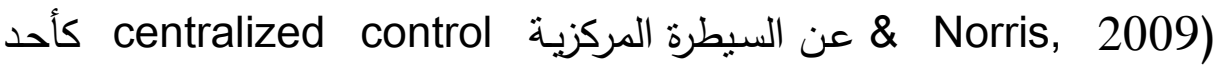
معوقات المشـاركة فى صنع القرار المدرسى فى المدارس الثانويـة بمصر ؛ فقد أجمع المشـاركون فى الدراسـة على أنهـ برغم كثرة المزاعم التى بروجها صـانعوا

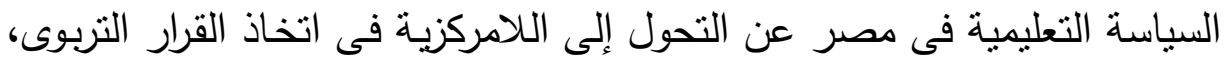
مازالت المدارس المصرية تفتقر إلى الاستقلالية فى صنع واتخاذ قراراتها بسبب وقوعها تحت السيطرة المركزية للمديريات والإدارات التعليمية، وقد اعتبر العديد من المشاركين ذلك العامل هو العائق الرئيس أمسام تطبيق أسلوب اتخاذ القرار بالمشاركة shared decision-making فى المدارس، وقد أوضحت نتائج تحليـل البيانـات أن التحكم المركزى فـى القـرارات التربويـة يحـول دون مشـاركة

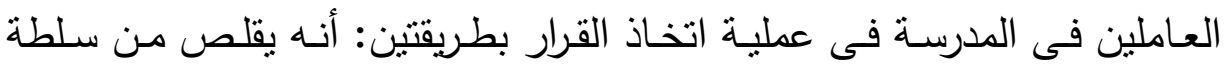

(1) يوسف عبدالمعطى مصطفى، (2002). أسلوب القيادة التحويليـة كـدخل لتحسين أداء

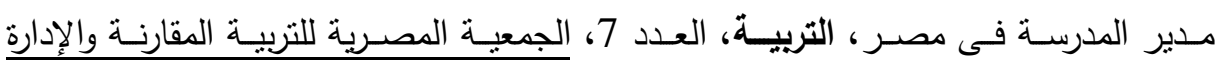

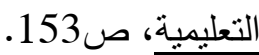


متطلبات تطبيق القيادة التوزيعية بمؤسسات رياض الأطفال فى ضوء بعض الاتجاهات د. أحمد محمد هميسة

المدرسـة فى اتخاذ القرارات ويحد من قدرة العاملين بها على صنع قرارات مهمة

وذات تـأثير على العمـل داخـل المدرسـة؛ فقد أظهـر تحليـل الوثائق المدرسـية

بالإضـافة إلى تحليل المقابلات أن القرارات التىى تتخذ فى المدراس عينـة الدراسـة

هـى قرارات هامشـية وروتينيـة يراهـا معظم العـاملين غيـر مـؤثرة على العمليـة

التعليميـة. وأنـه يثـجع مـدراء المـدارس وصـناع القـرار بهـا على تبنى أسـاليب أوتوقراطية فى الإدارة واتخاذ القرار؛ فقد رأى كثير من المشاركين أن اعتياد مدراء المدارس على تلقى التعليمات من خارج المدرسة، وخوفهم من التعرض للمساءلة، يمنعهم من توسيع دائرة المشاركة، ويشجعهم على التحكم فى عملية صنع واتخاذ

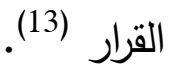

وتتفق هذه النتائج مع نتائج دراسات أخرى أجربت فى سياقات تربوبية مختلفة

منثل دراسـة مسالن وآخرون (Malen et al., 1990) ، ودراسـة والاس

، (Harris, 2003, 2004, 2005) ودراسـة هاريس (Wallace, 2001)

ودراسـة ميوجس وهاريس (Muijs \& Harris, 2006) ، وتشير نتائج هذه الدراسـات إلى أن الضـغوط التى يتعرض لها مدراء المدارس مـن قبـل السـلطات التعليمية المركزية تؤدى إلى تبنيهم أساليب غير ديمقراطية فى قيادة مدارسهم (14).

(2) Hammad, W. \& Norris, N. (2009). Centralised Control: A Barrier to Shared Decision-making in Egyptian Secondary Schools. International Studies in Educational Administration, 37(2): 60-73.

(1) see:

Malen, B., Ogawa, R, \& Kranz, J, (1990). Site-Based Management: Unfulfilled Promises, The School Administrator 47(2): 30-59.

Wallace, M. (2001). Sharing Leadership of Schools through Teamwork: A Justifiable Risk? Educational Management \& Administration, 29(2): 153-167.

Muijs, D. and Harris, A (2007). Teacher Leadership in (In)action. Three Case Studies of Contrasting Schools, Educational Management Administration \& Leadership, 35 (1): 111-1344.

DOI: $10.12816 / 0045606$ 184 
يتضـح مـن هذه المناقتــة التحليليـة لواقـع الممارسـات القياديـة فـى المـدارس المصرية والعوامل المؤثرة فيها أن هناك حاجة ماسة لنطبيق مداخل قيادية جديدة

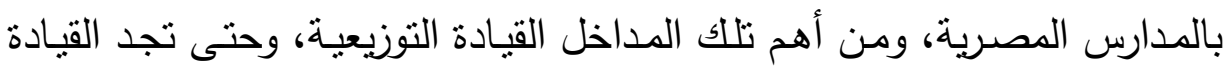

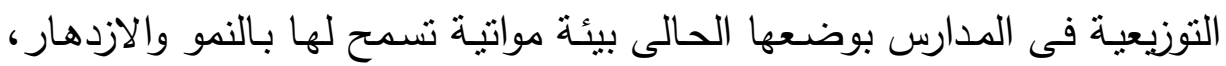
وحتى ينجح هذا النمط من القيادة فى المدارس، فلابد من توافر بعض الظروف

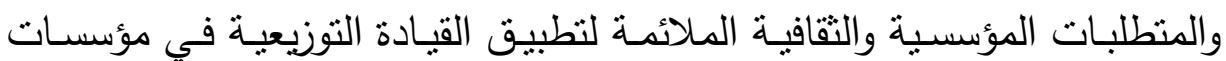

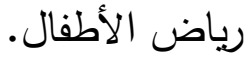

وتشــير الدراسـات المتعلقـة بالقيـادة التوزيعيـة إلى وجـود عدد مـن التحـديات الهيكيلة والثقافية المتأصلة فى معظم المدارس والتى تعوق التطبيق الفعال لهذا

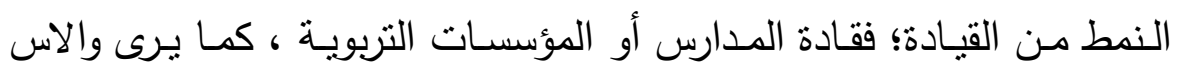
(Wallace, 2001) لا يعيشون فى عالم مثالى، ولذا فمن المتوقع أن يعتمد مدى المشاركة فى القيادة على عوامل ميدانية ومبادىء ترتبط بالمواقف وليست مطلقة، ومن هنا يرى كثثر من الباحثين ضرورة استكثاف هذه العوامل من خلال

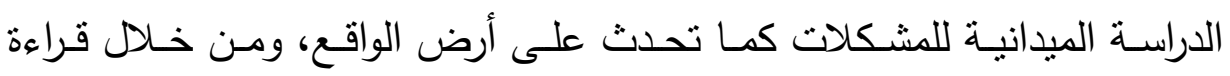
الأدبيات المتعلقة بالقيادة التوزيعية (15).

Harris, A. (2003). Teacher Leadership as Distributed Leadership: heresy, fantasy or possibility? School Leadership \& Management, 23 (3): 313-324.

Harris, A. (2004). Distributed Leadership and School Improvement: Leading or Misleading? Educational Management Administration \& Leadership, 32(1): 11-24.

Harris, A. (2005). Distributed Leadership. In B. Davies (Ed.), The essentials of school leadership (pp. 160-172). London: Paul Chapman.

${ }^{(2)}$ Wallace, M. (2001). Sharing Leadership of Schools through Teamwork: A Justifiable Risk? Educational Management \& Administration, 29(2): 153-167. 
وتتثير هاريس (Harris, 2003) إلى أن ثمة صعوبات تتعلق بروئية المعلمين

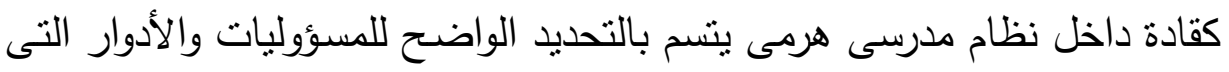

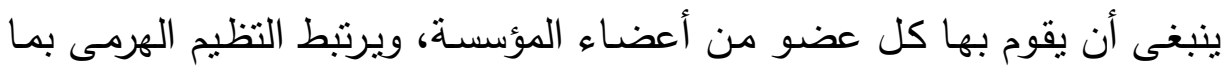

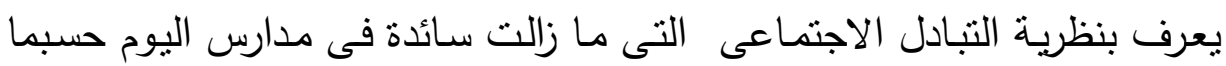

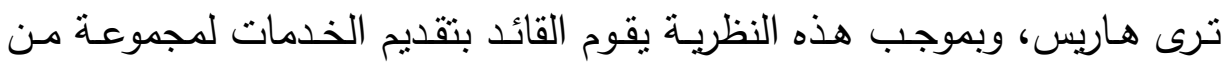
الأشخاص فى مقابل أن يمتثل هؤلاء الأشخاص لمطالبه، ويعتمد احتفاظ القائد

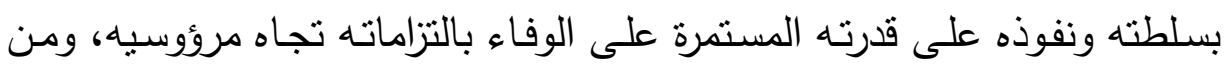

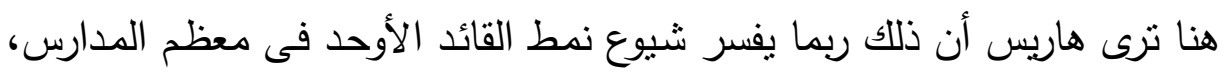

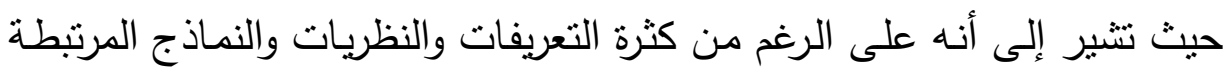

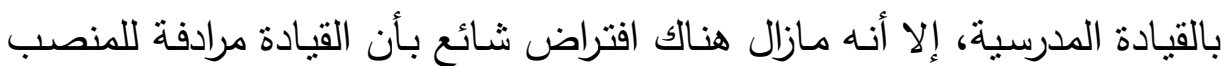

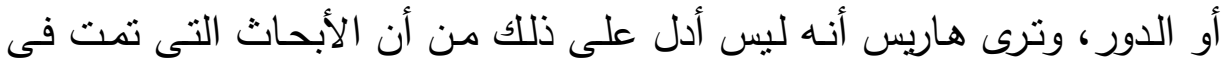

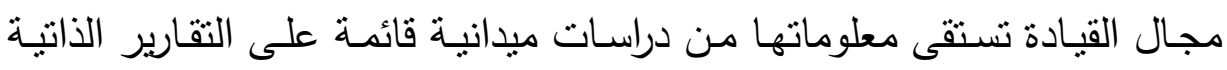
للمديرين، ومن ثم فهى تطرح دائما تصورا بطوليا للقيادة التى تتحصر غالبا فى درهي

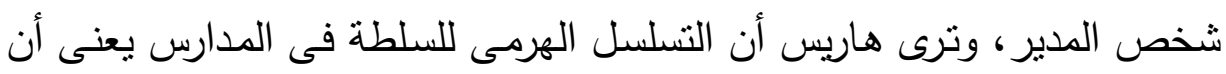

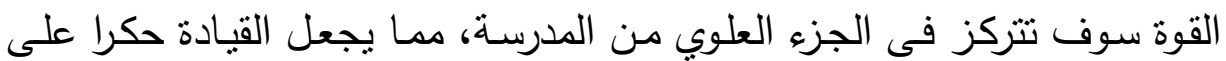
عدد قليل من الأفراد (16) ويتفق ميوجس وهاريس (Muijs \& Harris, 2003) مع هذا الطرح حيث

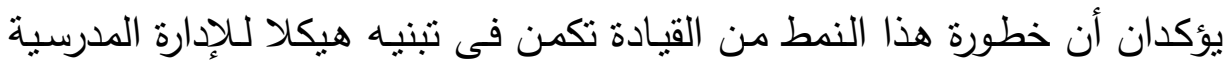
يتسم بصناعة القرار من أعلى إلى أسفل، وهو ما يعتبر عائقا يحول دون تفعيل القيادة التوزيعية وتطورها حيث يحد من استقلالية المعلمين، ومن ثم قدرتهم على الاضطلاع بأدوار قيادية؛ فالقيادة التوزيعية حسبما يرى ميوجس وهاريس لا يمكن

${ }^{(1)}$ Harris, A. (2003). Teacher Leadership as Distributed Leadership: heresy, fantasy or possibility? School Leadership \& Management, 23(3): 313-324.

DOI: $10.12816 / 0045606$ 
فرضها على الأفراد، بل يجب أن يشارك هؤلاء الأفراد فى تحديد الأدوار القيادية

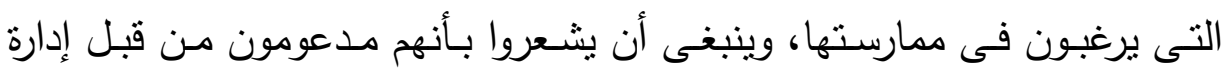
المدرسة فى قيامهم بهذه الأدوار (17).

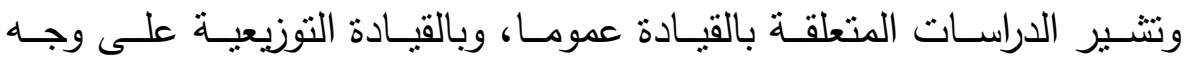

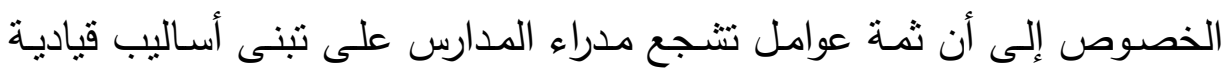

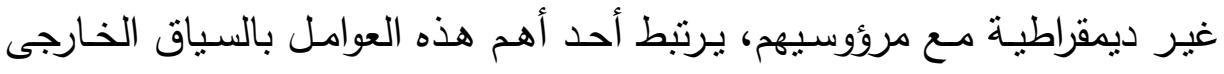

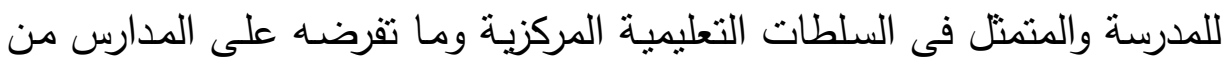
قيود وإجراءات للمحاسبة تمثنل عبئًا على المعلمين والإداريين، وتجعل عمليـة توزيع القيادة أمرا بالغ الصعوبة؛ فكما يشير والاس (Wallace, 2001) تقوم

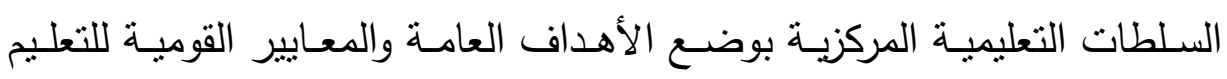
وتطلب من مدراء المدارس أن يقوموا بصياغة رؤية المدرسة وتحديد اتجاهها بما بواهي يضمن تحقيق هذه الأهداف والمعايير ، ولكى يستطيع المدراء القيام بهذه المهية

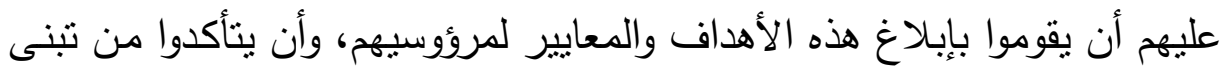
المرؤوسين لها، ومن ثم القيام بتتفيذها على الوجها الذى تريده الحكومة المركزية،

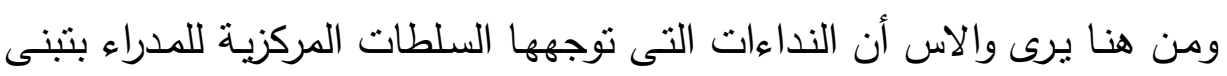

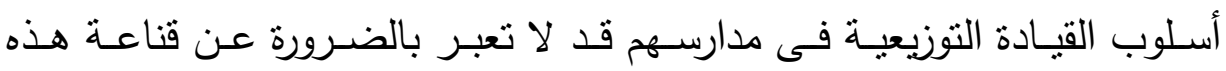

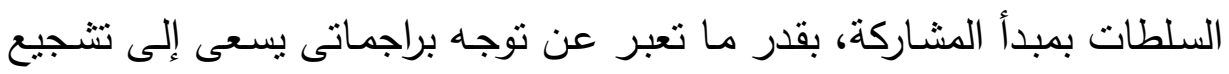

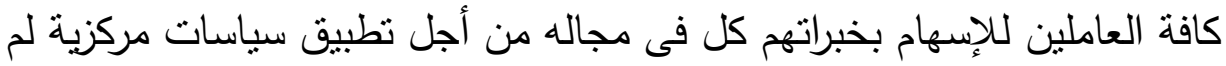
(18)

يشاركوا فى وضعها

${ }^{(2)}$ Muijs, D. and Harris, A (2007). Teacher Leadership in (In)action. Three Case Studies of Contrasting Schools, Educational Management Administration \& Leadership, 35(1): 111-1344..

(1) Wallace, M. (2001). Sharing Leadership of Schools through Teamwork: A Justifiable Risk? Educational Management \& Administration, 29(2): 153-167. 
منطلبات تطبيق القيادة التوزيعية بمؤسسات رياض الأطفال فى ضوء بعض الاتجاهات د. أحمد محمد هيسة

لذلك يجد الباحث أن مجمل نتائج الدراسات المتعلقة بالقيادة التوزيعية وقيادة

المعلم إلى أن الكثير مـن المعلمين ربمـا لا يكونون بالضـرورة متحمسين لفكرة

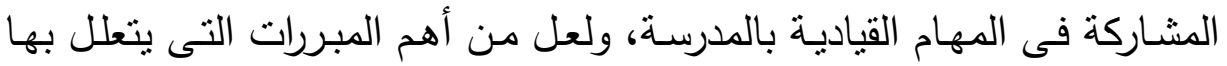
هؤلاء المعلمون هو اعتقادهم بأن تلك المشاركة سوف تلقى على عاتقهم مزيدا من المسؤليات التى يعتقدون أنها تقع خارج نطاق عملهم كمعلمين. حيث يرى (Hammad., 2010) أن التعاون بين أعضاء الجماعة داخل مستويات المنظمة يعد عنصرا حيويا في فكرة القيادة التوزيعية، والتي بدونها يحل الصراع والخلاف بين مختلف الأفراد؛ فقي ظل القيادة التوزيعية ينبغي أن تتغير أنماط السلوك بحيث يصبح هناك نوع من الاندماج والتعاون والتفاعل وإمكانية

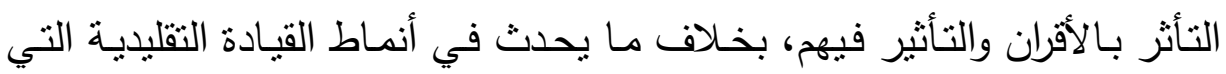
تسير من أعلي لأسفل، وتتشير الدراسـات المتعلقة بالقيادة التوزيعيـة إلى أهميـة

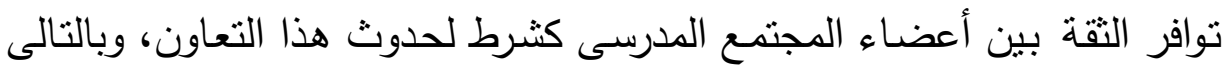
نجاح تطبيق القيادة التوزيعية داخل المدرسة؛ فالتقة تلعب دورا حيويا فى تتكيل

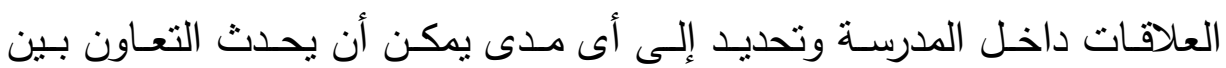

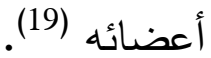

وهناك عدد من المتطلبات التي ينبغي أن يقوم بها القادة وفقا لمفهوم القيادة التوزيعية منها (20): 1 - وضع الروئية والرسالة.

${ }^{(2)}$ Hammad, W. (2010). Teachers' Perceptions of School Culture as a Barrier to Shared Decision-making (SDM) in Egypt's Secondary Schools. COMPARE, 40(1): 97-110..

${ }^{(20)}$ Martinez, Cecilia et al. (2005) leadership alignment the challenges of distributed leadership, paper presented at the Annual Meeting of the American Education Research Association Montrel, pp. 16

DOI: $10.12816 / 0045606$ 


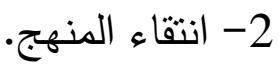

3- توفير المصادر والوسائل.

$$
\begin{aligned}
& \text { 4- توفير فرص التعلم. } \\
& \text { 5- تدريب المعلمين. } \\
& \text { 6- تقديم التشجيع. }
\end{aligned}
$$

وتتمنل أهم أهداف القيادة التوزيعية في المشاركة في القيادة داخل المؤسسات

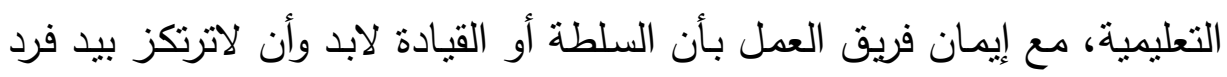

واحد ، بل وتصبح متاحة للجميع بما يدعم مفهوم الفريق القيادي (21). كما أن الهدف الرئيس من القيادة التوزيعية هو جعل فئه فريق الإدارة والموظفين

في اتصال مع أهداف وقيم المؤسسة ورويتها (22. وعن أدوار المعلم داخل المدرسة في ظل القيادة التوزيعية ؛ فهي أدوار قيادية

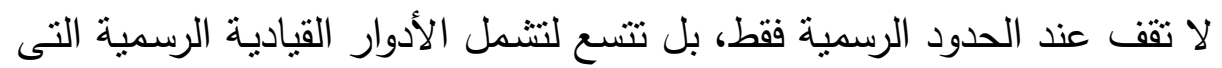

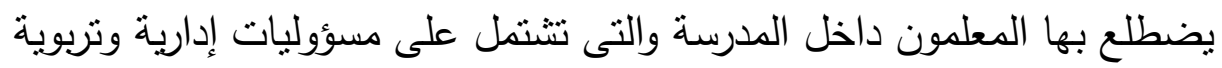
منل رؤساء الأقسام ومنسقى المواد والمراحل، بالإضافة إلى الأدوار القيادية غير لئل الرسمية كالتدريب وقيادة فريق عمل جديد وتتكيل مجموعات للقيام بالبحوث

الإجرائية (23)

(21) امجد محمود درادكة والسيد محمد جابر ظافري (2014). درجه ممارسـه القياده التوزيعيه لدى مديرى مدارس التعليم العام لدى مدينه الطائف ، مجلة البحث العلمى في التربية ، العدد

(22) عبدالحكيم ربيع واحمد عز الدين شيت ومني محمد (2016) ـ تأثنر بعض ابعاد القياده

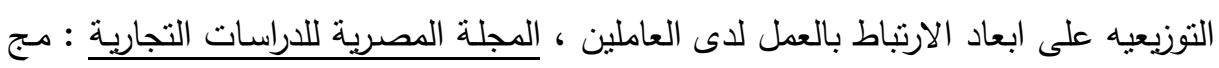

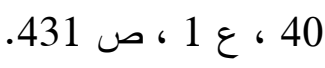
(4) أحمد عبدالفتاح الزكي ووحيد شاه بور حماد (2014) القيادة النوزيعية :أسسها ومنطلبات

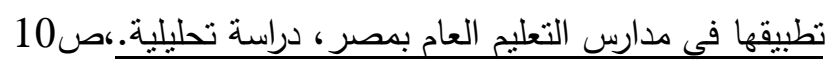


لكن في ظل جهود وزارة التربية والتعليم نحو إعداد مديري المدارس وذلك عبر برامجها بالأكاديمية المهنية للمعلمين ، نجد أنها تسعي نحو تدريبهم على الإلمام بالقوانين الإدارية والمهام المنوطة بهم بصفتهم مديرون يوكل إليهم كل الأعمال

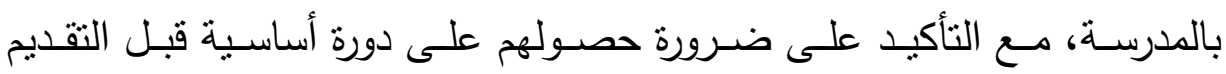

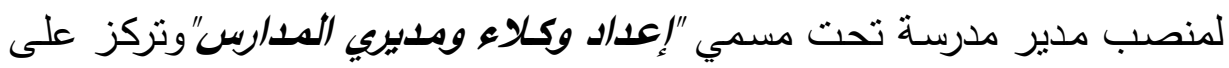

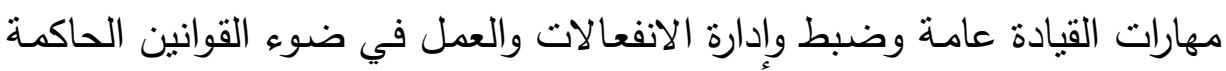

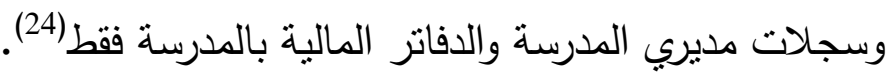
كما تتحدد ممارسات القيادة التوزيعية في كيفية تفاعل القادة مع الأخرين ، كما

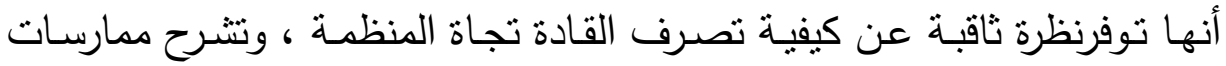

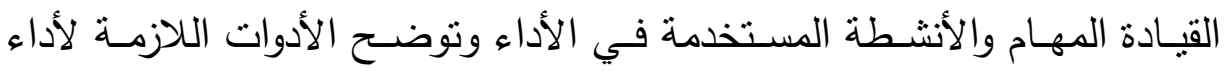
المهام ، وتفسر ممارسات القيادة "كيف يحدد ويقدم وينفذ قادة المدارس تفاعلهم

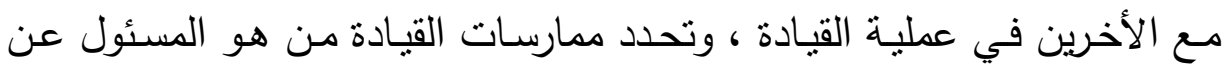

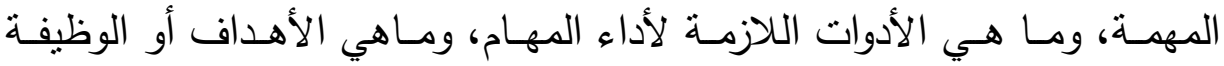

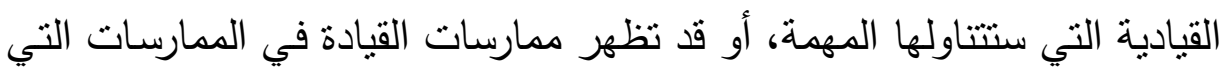
توفر التحدي الذي يساعد المنظمـة على القيام بـالأداء من خـلال توزيع الأدوار على التابعين (25) لـذلك يـرى الباحث أنـهـ قـد أصبحت الحاجـة ملحـة لتطبيـق القيـادة التوزيعيـة بمؤسسـات رياض الأطفال، وحتى تجد القيادة التوزيعيـة بوضعها الحسالى بيئة

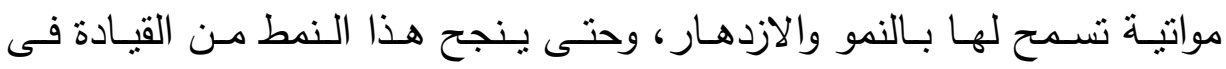

\section{(1) وزارة التربية والتعليم:التتمية المهنية لديري الددارس، 2017، ص112.}

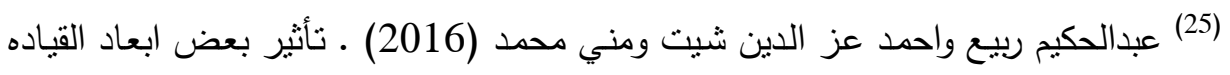

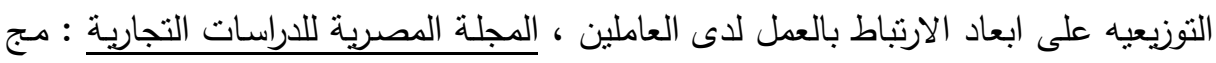

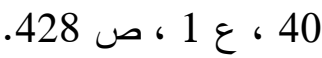

DOI: $10.12816 / 0045606$ 
مؤسسات رياض الأطفال، فلابد من توافر بعض الظروف والمنطلبات المؤسسية

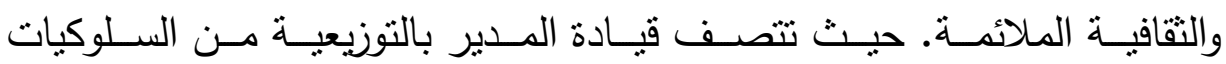

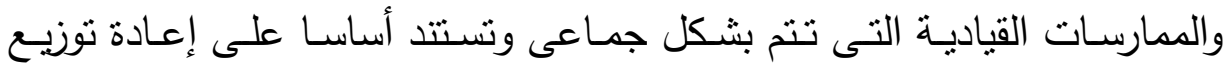
السلطة داخل المؤسسات بحيث تمتذ إلى أعضاء الهيئة التدريسية. ويطرح فروست وديورانت (Frost \& Durrant, 2003: 174) أربع قضايا يسوقها الباحثون كحجج لتأييد فكرة القيادة التوزيعية والدعوة لتطبيقها فى المدارس وهى (26).: فعالية المدرسـة(school effectiveness) : فالمدارس الفعالة هى التى تصل إلى درجة عالية من اتساق الممارسات وتماسك القيم، ولا يتأتى ذلك عن الك الكي

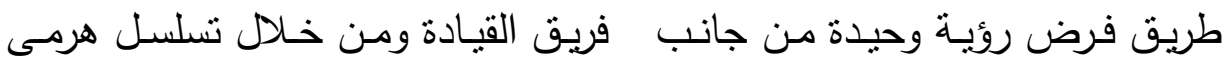

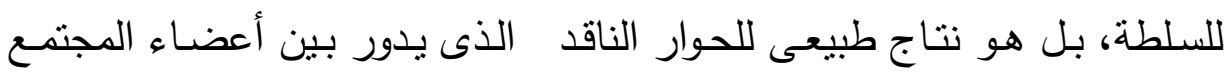

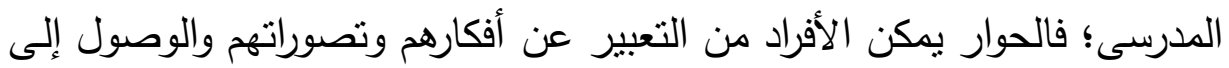
فهم مشترك أكثر عمقا. تحسين المدرسـة(school improvement) : فالتحسين طويل الأجل والمستدام لجودة التعلم يعتمد أساسا على ما يقوم بـه المعلمون من عمل داخل

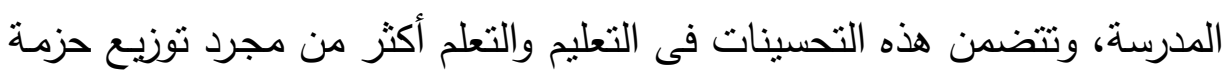

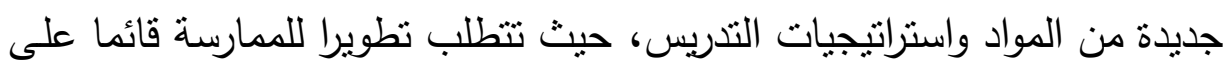
طرح الأسئلة باستمرار حول القيم والمعتقدات والفهم، لذلك دون مشاركة المعلمين لن يكون هنالك تطوير حقيقى، حيث إن تحسين الممارسة المهنية يحتاج إلى نوع

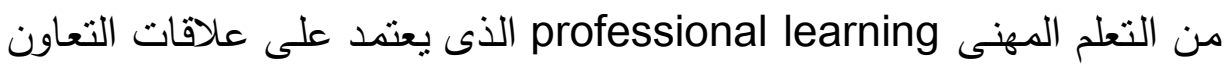
والزمالة.

(3) نقلاعن: أحمد عبدالفتاح الزكي ووحيد شاه بور حماد مرجع سابق ،ص14 
منطبات تطبيق القيادة التوزيعية بمؤسسات رياض الأطفال فى ضوء بعض الاتجاهات ـ. أحمد محمد هميسة

معنويات المعلمين والاحتفاظ بهم (teacher morale and retention)

: وتدحض هذه الحجة الادعاء بأن مشكلة انخفاض المعنويات في مهنة التعليم

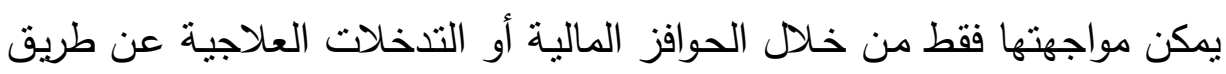
الإرشاد النفسى مثلا؛ فمشكلة انخفاض المعنويات ترجع أساسا إلى تجاهل مهنية المعلمين وعدم الإيمان بقدرتهم على إحداث فروق ذات مغزى فى مدارسهم من الإنيات خلال إثراكهم بفاعلية فى عملية التغيير التربوى.

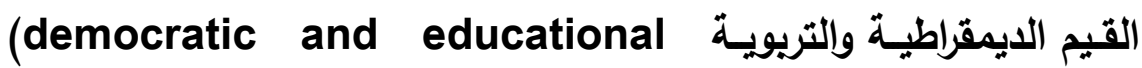

:values)

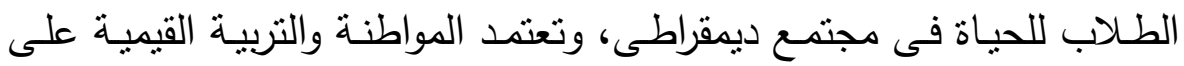

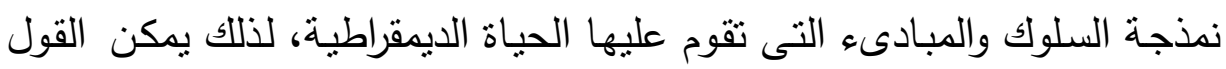

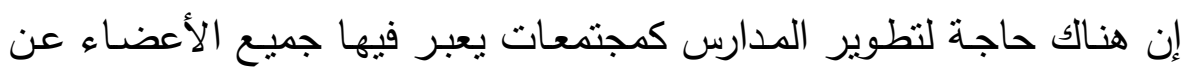
آرائهم، ويسمح لهم بمساحة لتحقيق قدراتهم البشرية وممارسة القيادة. وقد أوضح جرون (Gronn, 2002) (27) نفس الفكرة مؤكدا أن هناك شكلين ميزين من القيادة التوزيعية وهما: (additive): وهو يشير إلي حاصل جمع السلوكيات القيادية aggregated leadership behavior

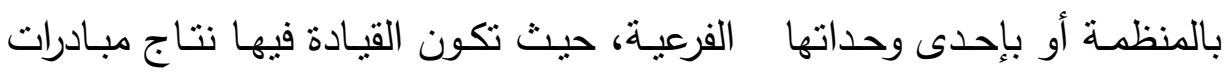

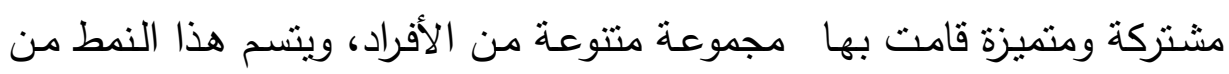

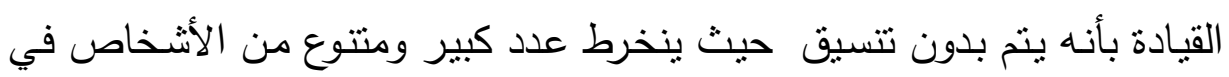

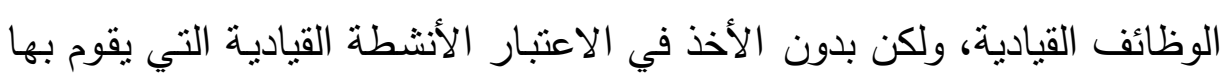

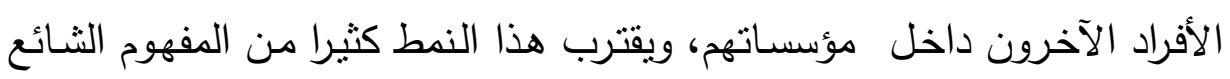

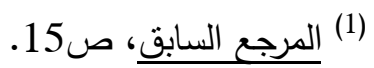

DOI: 10.12816/0045606

192 
لاى البعض والقائل بأن" كل فرد هو قائد everyone is a leader "، كما يتفق مع مفهوم القيادة التوزيعية التى تؤخذ taken كما يراه ماكبيث ورفاقه.

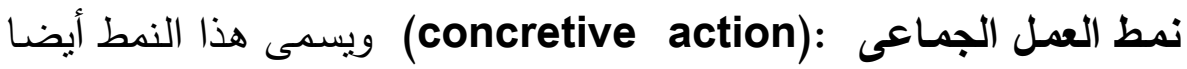
بالنمط الكلى holistic ، ويشير إلي العلاقات التعاونية والتشـاركية التي تتم بوعي بين بعض أو معظم أو جميع مصادر القيادة داخل المنظمة، ويشير هذا المفهوم

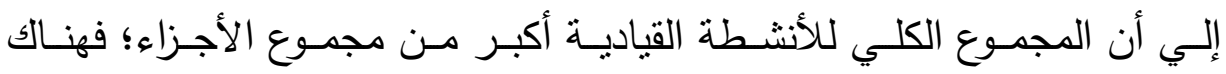

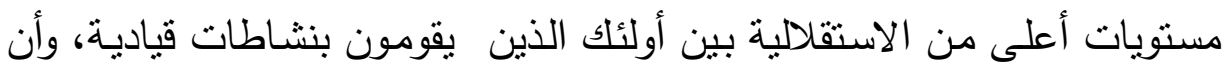
التأثير الذي يقومون به ينتج عن العمليات الاجتماعية والديناميكية التي تؤدي إلي التي

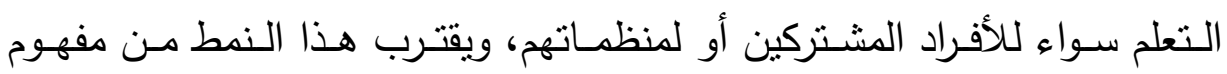
ماكبيث وزملائه عن القيادة التوزيعية التى تعطى.

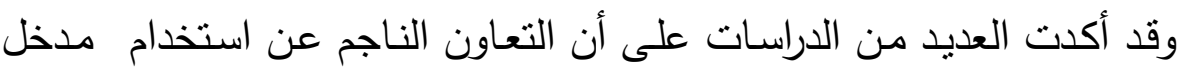

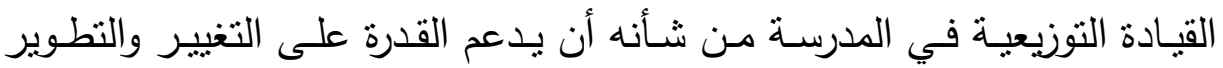
والتحسين الذي ترغب إدارة المدرسة في تحقيقه (28).

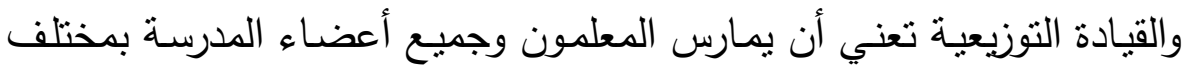
مستوياتهم ورتبهم عدداً من الأدوار القيادية الرسمية وغير الرسمية (29).

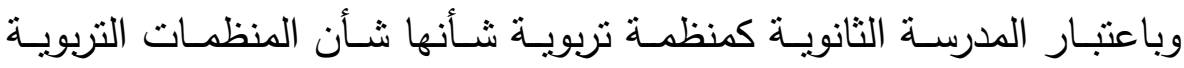
والخدمية ، لذلك اهتمت الوزاره برفع كفاءة مديرى مؤسسات رياض الأطفال مهنياً

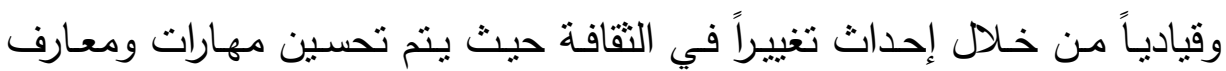

${ }^{(28)}$ Harris, Alma (2012) Distributed Leadership in Schools, Leading or Misleading? Paper presented at the British Educational Leadership Management and Administration Society Conference, Birmingham, England, September 2002 , P4.

${ }^{(29)}$ Leathwood, k.et al (2007) Distributed leadership to make schools smarter: taking the ego out of the system, leadshp and policy in schools, 6 (1), pp. 37. 
العاملين في المنظمة وتعزيز علاقاتهم الإنتاجية بحيث تكون مثمرة مـع بعضهم البعض، وهذا يتطلب العمل بشكل جماعي لتحقيق النجاحات المستمرة وهو الأمر

الذي يمكن تحقيقه من خلال القيادة التوزبعية (30). • مصطلحات البحث: يتم استخدام المصطلحات التالية

\section{"القيادة التوزيعية (Distributed Leadership)}

تعرف القيادة التوزيعية بأنها "القدرة على التأثير في الآخرين من أجل تحقيق أهداف وأغراض محددة" (31).

وتعرف القيادة التوزيعيـة "بأنها قدرة مدير المدرسـة على ترك قنوات الاتصسال مفتوحسا تمامـاً مسع العـاملين، ومنحهم التقة التامسة ومشـاركتهم في اتخـاذ القرارات وتشجيعهم على إبداء الرأي بما يخدم ويفيد الجماعة" (32). وتعرف بأنها "تتوع مصادر التوجيه والإرشـاد تبعا للخبرات الموجودة بالمؤسسـة والتي تصبح منرابطة بفضل التقافة المشتركة". (33). ويعرف الباحث القيادة التوزبعيـة إجرائياً بأنها: "مدخل إجرائي يقوم على منح مدير المدرسة عدداً من الأدوار القيادية الرسمية والغير رسمية للمعلمين وذلك من خلص المشاركة في صنع القرار واتخاذه، والتعاون والمشاركة في تحقيق أهداف المدرسة، وتحسين أدائها وتطويرها."

2- الممارسات القيادية :

وتعني ممارسة الأمر لغوباً "عالجه وزواله وشرع فيه". (34)

(1) فاروق فلية، أحمد الزكي، ، معجم مصطلحات التربيـة لفظا واصطلاحاً، دار الوفاء لدنيا

$$
\begin{aligned}
& \text { الطباعة والنشر ، الإسكندرية، 2014م ، ص193 } \\
& \text { (2) سالم سعيد القحطاني، مرجع سابق، ص81. }
\end{aligned}
$$

${ }^{(33)}$ Elmore, R. Opt Ct. , P15

(34) المنجد في اللغة والاعلام ، ط34 ، بيروت ، المكتبة الثرقية ، 1994.

DOI: $10.12816 / 0045606$ 
وتعرف بأنها ممارسـة الجهد المخطط والمنظم للوصول إلى تحقيق الأهداف

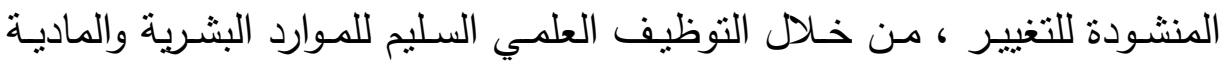

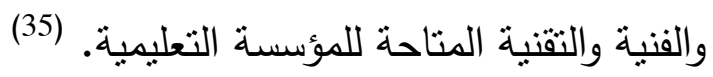
أو (36) : هي عملية يسعى من خلالها كل من القائد والتابعين إلى رفع كل منهما الآخر إلى أعلى مستويات الدافعية والأخلاق.

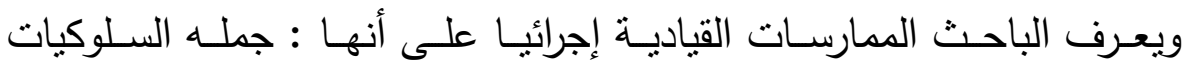

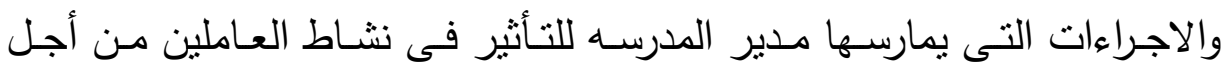
تحقيق أهداف المدرسة. • منهج البحث : في ضوء أهداف البحث والأسئلة يتم استخدام: 1- المنهج الوصفي الذي يعبر عن الظاهرة المراد دراستها تعبيراً كمياً وكيفياً، والذي يعمد إلى تحليل الظاهرة وكثف العلاقات بين أبعادها المختلفة من أجل تفنيدها والوصول إلى استتناجات لتحسين الواقع وتطويره.

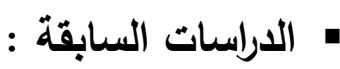

• دراسة ليثود وآخرين (Leithwood, 2007) بعنوان" القيادة التوزيعية في مؤسسات رياض الأطفال."

(35) منى مؤتمن:قيادة التغيير في المؤسسة النربوية، بحث ترقية محكم- وزارة التربية الاردنية ، 2014 ، صنية

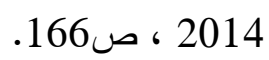

(36) يوسف عبدالمعطي مصطفى:اسلوب القيادة التحويليـة لتحسين اداء مدير المدرسـة في

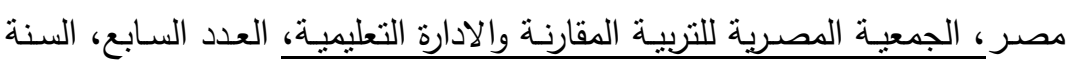

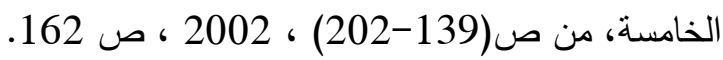

${ }^{(37)}$ Leithwood, K. (2007), Distributed Leadership in Schools, paper presented at the Annual Meeting of the American Educational Research Association, Chicage, IL, march 2428, p. 1 
منطلبات تطبيق القيادة التوزيعية بمؤسسات رياض الأطفال فى ضوء بعض الاتجاهات د. أحمد محمد هيسة

قامت هذه الدراسة بفحص الدور القيادي للمعلم وفحص التأثير النسبي للقيادة التي يمارسها المديرون والمعلمون، وقد قامت الدراسة بعمل مسح لجميع العاملين في إحدى إدارات التعليم الكبرى وعقدت مقابالات شخصية مع المعلمين في ست مؤسسات رياض أطفال.

$$
\text { وخلصت الدراسة إلى عدد من النتائج منها: }
$$

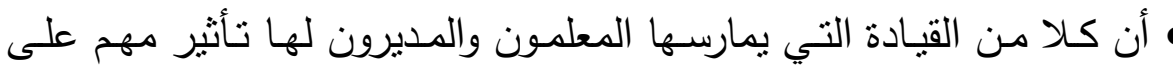

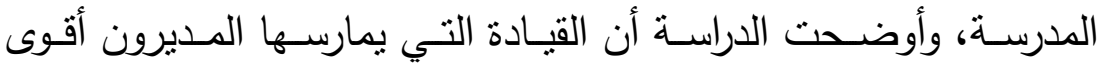
بحوالي التلث من القيادة التي يمارسها المعلمون.

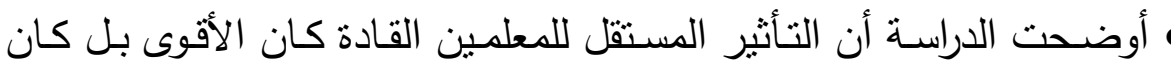

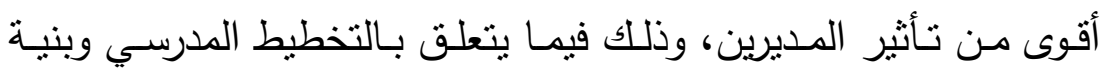

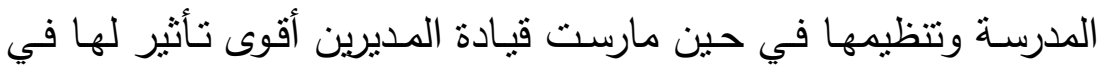
جوانب منل التخطيط والبنية والتنظيم، وكذلك في رسالة المدرسة وثقافتها. •أثـارت الدراسـة إلى أن خصـائص المعلم القائد تتطوي على شـخص يعتمد

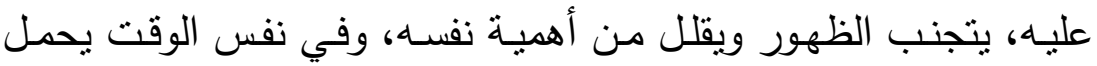

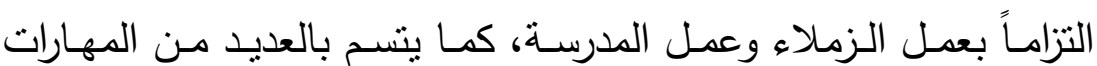

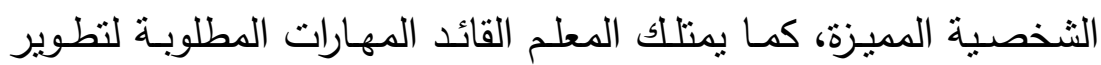
البرامج واستخدامها بشكل جماعي، مستفيداً من خبراته بالسياسة التعليمية والمادة الدراسية والمجتمع المحلي وطلاب المدرسة.

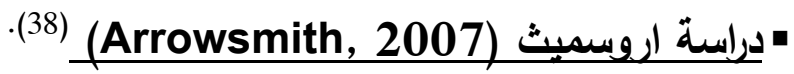

(38) Arrowsmith, Trevor (2007), Distributed Leadership in Secondary Schools in England: The Impact on the Role of The Headteachers and Other Issues, management in Education, Vol, 21, pp. 21- 27. 
بعنوان" القيادة التوزيعية في مؤسسات رياض الأطفال في إنجلترا، نأثيرها على

$$
\text { مدير المدرسة وقضايا أخرى." }
$$

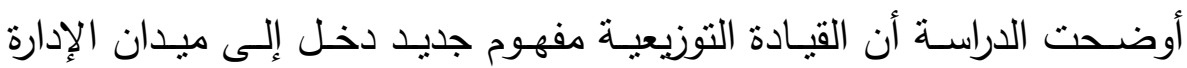

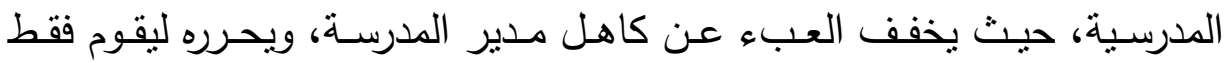

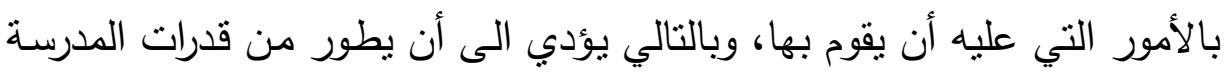

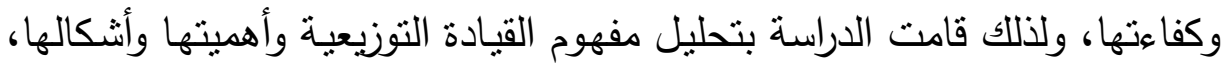

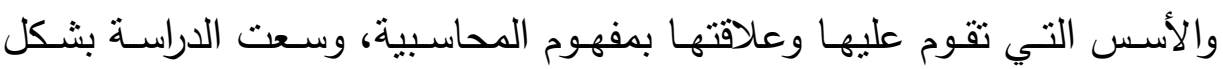
أساسي للإجابة على سؤالين يدوران حول ما يقوم مديرو المدارس لنطوير القيادة

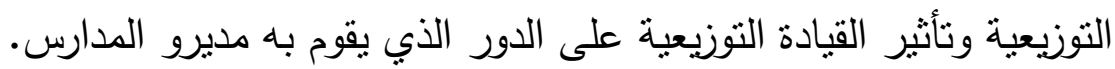

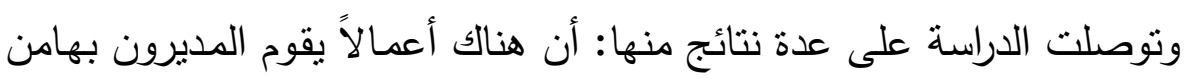

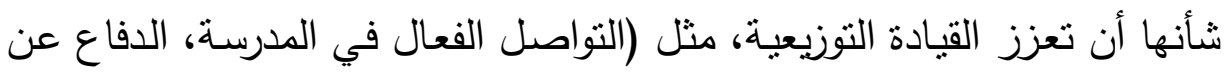

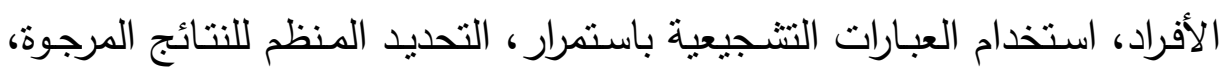

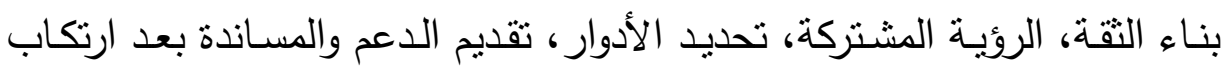
الأخطاء).

" دراسة لبثود وحانتزي (Leithwood and Jantzi, 2008)

$$
\text { بعنوان" القيادة التوزيعية ومشاركة الطلاب في المدرسة." }
$$

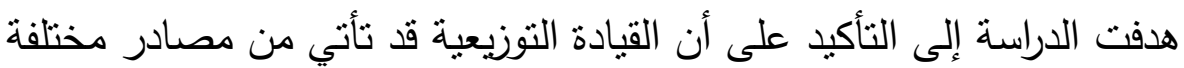

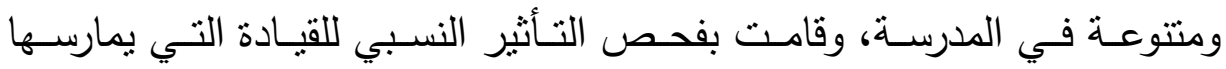

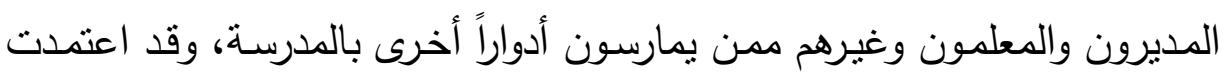

(39) Leathwood, Kenneth \& Jantzi, Doris (2008), Distributed Leadership and Student Engagement in schools, paper presented at the Annual meeting of the American Educational Research Association, San Diego CA, April 13-17, p.123. 
منطلبات تطبيق القيادة التوزيعية بمؤسسات رياض الأطفال فى ضوء بعض الاتجاهات د. أحمد محمد هيسة

الدراسـة على مستح لعدد 2727 معلمـاً و 9025 تلميذا في مئسة وعشرة مدرســة ابتدائية وثانوية في أونتاريو بكندا.

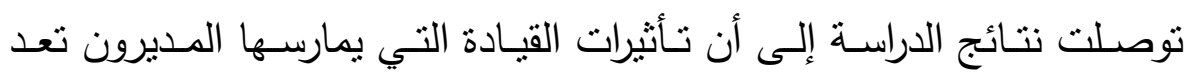
منواضعة وغير مباشرة، وتفسر التغير والتتوع الواضح في مشاركة الطلاب.

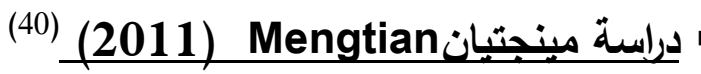

بعنوان "القيادة التوزيعيـة وفعالية الذات للمعلمين : دراسـات حالة على ثلاث

$$
\text { مدارس صينية في شنغاهاب". }
$$

فحصت الدراسة القيادة التوزيعية وتأثيرها على كفاءة المعلمين الذاتية في ثناث

$$
\text { مدارس صينية في شنغهاي. }
$$

ولتحقيق هدف الدراسـ فقد استخدم الباحث منهج دراسـه الحاله وكانت ادوات

الدراسه عباره عن استبيان و 13 مقابله فرديه بالاضافه الى 4 ايام مشاركه لجميع لباهي درانه

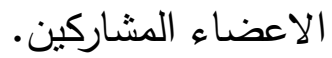

تم تطبيق منهج طرق مختلفةة لجمـع البيانات النوعيـة والكميـة من المدارس الثناث. وتم جمع البيانات البحثية من خلدل استبيان واحد ، و 13 مقابلة فردية،

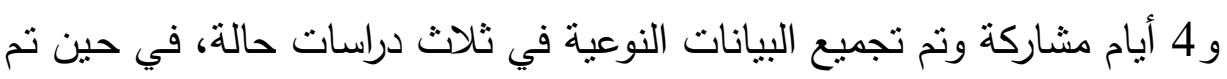

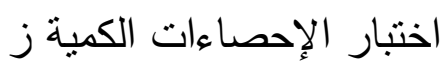

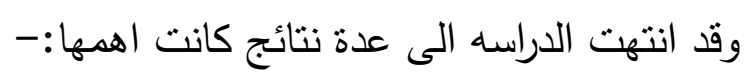

1-ان القياده التوزيعيه يتم ممارستها فى المدارس عينه البحث بأنثكال مختلفه حيث يقوم مديرى المدارس بتمكين المعلمين على المستوين الفردى والجماعى

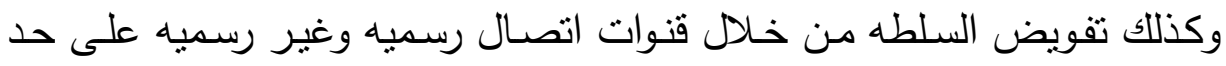

${ }^{(40)}$ Mengtian (2011). Distributed leadership and Teachers' self-efficacy: The case studies of three chinese schools in shanghai, Master's thesis , November, Department of education , Institute of educational leadership, University of jyväskylä.

DOI: $10.12816 / 0045606$ 
سواء وفقا للحاله. كما يمكن توزيع القياده المدرسيه امـا على شكل طويل الاجل او مخصص قصبر الاجل.

2- وقد اكدت بيانات المسح الكمى للنتائج النوعيه انها فى المتوسط حيث ان

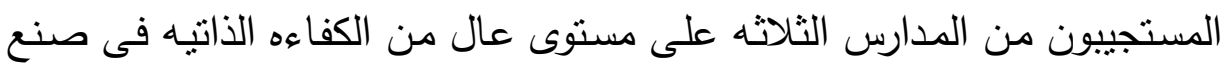
القرار والعلاقات الثخصيه والتعاون وجودة التدريس وكذلك تأثثر المعلمين على منى عنى ثقافه المدرسه وبخاصه المعلمين مادون سن الاربعين. 3- هنالك تعاون افقى بين القاده المعلمين وتعاون رأسى بين مديرى المدارس الدئ وقاده المعلمين. 4-تلعب قيادات المعلمين وتمكين المدراء دورا رئيسا فى توزيع القياده.

\section{"داسية ألما هاريس (Harris, 2012)}

\section{بعنوان" القيادة التوزيعية في المدارس تقود وتوجه أم تضلل؟؟."}

هدفت الدراسة النظر إلى الممارسات القيادية التي تتم في المدارس من منظورد التهر موزع، اعتمد على النتائج التي استقتها الدراسـة ميدانياً من دراستين معاصرتين للقيادة المدرسية الناجحة، ومن البحوث الدولية في مجال القيادة التوزيعية، حيث درسـت إحداها التحديات والمشكلات التي تواجـه القيادة الفعالـة في المدرسـة، ودرست الأخرى الإدارة الفعالة للمدارس، كما قدمت الدراسة تحليلا لواقع ممارسة القيادة التوزيعية بالمدارس. وتوصلت الدراسة إلى عدة نتائج منها:

(41) Harris, Alma (2012) Distributed Leadership in Schools, Leading or Misleading? Paper presented at the British Educational Leadership Management and Administration Society Conference, Birmingham, England, September 2002. 
منطلبات تطبيق القيادة التوزيعية بمؤسسات رياض الأطفال فى ضوء بعض الاتجاهات د. أحمد محمد هيسة

•أن ممارسة القيادية بالمدارس هي ذات طبيعة موزعة، حيث يتحقق ذلك من

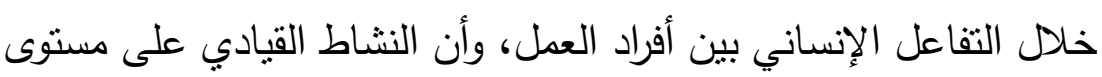
المدرسة أكثر منه على مستوى الفرد. •أن المنظور للقيادة التوزيعية يقدم وجهة نظر جديدة ومهئة يمكن من خلالها فهم وتحليل الممارسات القيادية بالمدارس.

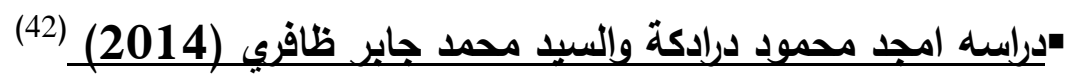
بعنوان:" درجه ممارسه القياده التوزيعيه لاى مديرى مدارس التعليم العام لدى مدينه الطائف". هدفت الدراسـه الى تحديد درجه ممارسـه القياده التوزيعيه لدى مديرى مدارس

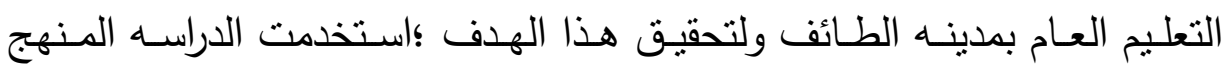
الوصفى التحليلى،كم تم بناء وتطوير استبانه مكونه من (34) فقره وتكون مجتمع

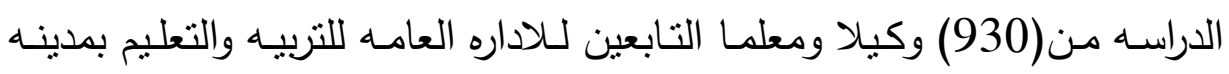
الطائف (بنين) للعام الدراسى 1435-1436 هجرى .

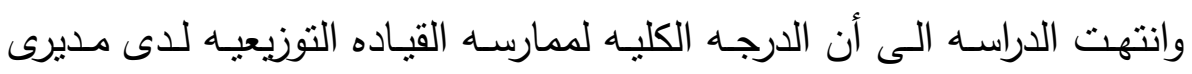

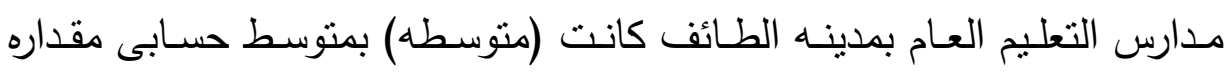

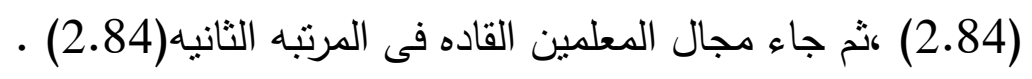

(42) امجد محمود درادكة والسيد محمد جابر ظافري (2014). درجه ممارسه القياده التوزيعيه

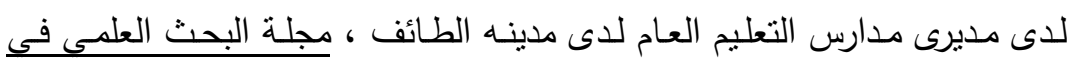

$$
\text { التربية ، العدد (15). }
$$


• • دراسده ايمن فؤاد ابو زر (2015) (43).

بعنوان "درجه ممارسـه مديرى المدارس الثانوبـه بمحافظله غزه للقياده التوزبعيه

وعلاقتها بمستوى الفاعليه الذاتيه للمعلمين".

هدفت الدراسـه لقيـاس درجـه ممارسـه مديرى المدارس بمحافظـات غزه للقيـاده

التوزيعيه الثانوبه بمحافظه غزه وعلاقتها بمستوى الفاعليه الذاتيه لدى معلمبهم.

واستخدمت الدراسه المنهج الوصفى( التحليلى ) مستخدما استبانه لقياس درجه ممارسـه مديرى المدارس الثانويـه بمحافظله غزه للقياده التوزيعيه من وجهه نظر المعلمين.

كما استخدمت استبانه اخرى لقياس مستوى الفاعليه الذاتيه لدى المعلمين وكان مجتمع الدراسـه مؤلف مـن جميـع معلمين المرحلـه الثانويـه بمحافظـه غزه للعـام الدراسـى 2014- 2015 والبـالغ عددهم 4857 معلمـا ومعلمسه وتكونـت عينـه الدراسه التى تم اختيارها عشوائيا من 400 معلم ومعلمه واستخدمت برناج الرزم الاحصائيه لتحليل معالجه البيانات. وتوصلت الدراسه الى : - بلغت درجه ممارسه مديرى المدارس الثانوبه بمحافظه غزه للقياده التوزبعيه مـن وجهـه نظـر المعلمـين 76.08\% وبدرجـه كبيـره حسـبا للمحــك المسـتخدم بالدراسـه.

- وجـود علاقهه طرديـه ذات دلالـه احصـائيه بـين ممارسـه مـديرى المـدارس الثانوبه بمحافظه غزه للقياده التوزبعيه ومستوى الفاعليه الذاتيه لمعلمبهم.

(43) ايمن فؤاد ابو زر (2015).درجهه ممارسه مديرى المدارس الثانويـه بمحافظه غزه للقياده التوزيعيه وعلاقتها بمستوى الفاعليه الذاتيه للمعلمين". رسالة ماجستير غير منشيورة ، الجامعة الاسلامية بغزة. 
منطبات تطبيق القيادة التوزيعية بمؤسسات رياض الأطفال فى ضوء بعض الاتجاهات ـ. أحمد محمد هميسة

لدراسه ابناس محمد اسماعيل عبدالله وعباس عبدمهي (2015) (44).

بعنوان: القياده الموزعه لمديرى المدارس الثانويـه الخاصـه فى محافظه عمان وعلاقتها بالتفاؤل الاكاديمى للمعلمين من وجهه نظرهم.

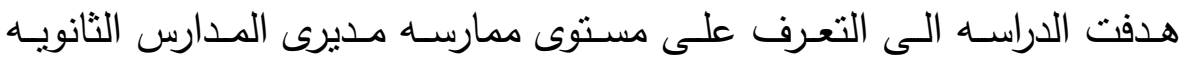
بمحافظه عمان للقياده التوزيعيه وعلاقتها بمستوى التفاؤل الاكاديمى للمعلمين من هن هنئ وجها نظرهم - وحهن

واستخدمت الدراسه المنهج الوصفى. واستخدمت الدراسه استبانتان ، الاولى لقياس مستوى ممارسـه مديرى المدارس لفس

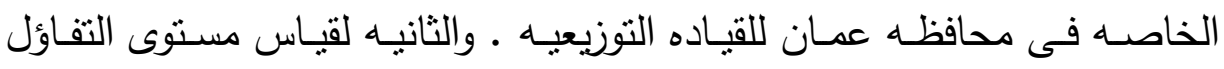
الاكاديمى لدى المعلمين وقد تكونت عينه الدراسـه من( 341) معلما ومعلمهـ وتم اختيارهم بالطريقه الطبقيه العشوائيه النسبيه... وتوصلت الدراسه الى النتائج الاتيه:-ان مسـتوى ممارسـه مديرى المـدارس الثانويـه الخاصـهـ فـى محافظـه عمـان

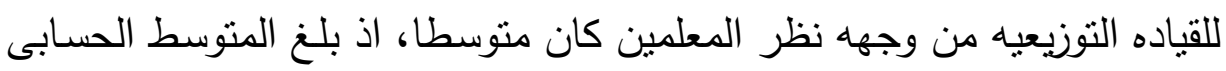
(3.23) بانحراف معيارى (0.55).

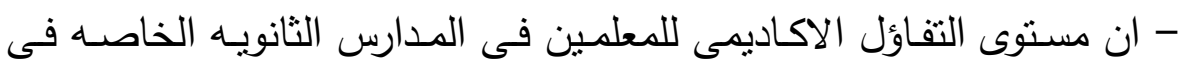
محافظه عمان من وجهه نظرهم كان متوسطا،و بلخ المتوسط الحسابى (3.46) بانحراف معيارى (0.51).

(44) اينـاس محمد اسماعيل وعباس عبدمهدي (2015). القياده الموزعـه لمديرى المـارس

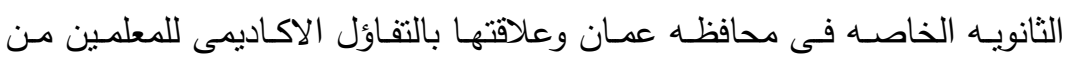

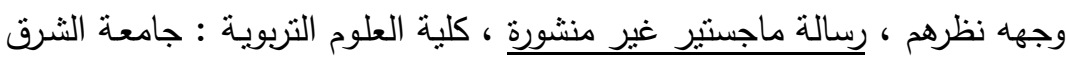

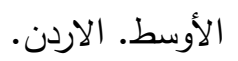




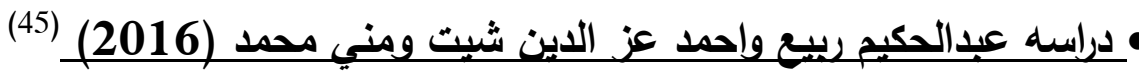
بعنوان" تأثثير بعض ابعاد القياده التوزيعيه على ابعاد الارتباط بالعمل: دراسـه

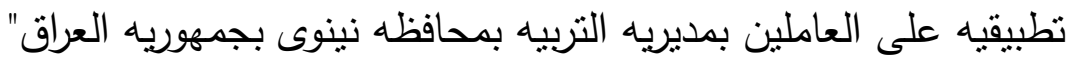

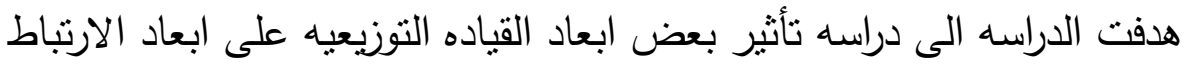

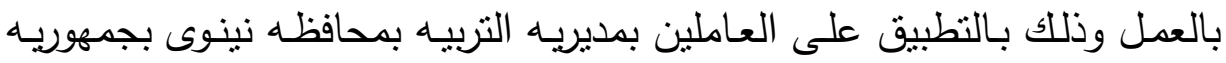
العراق.

ولتحقيق هذا الهدف استخدمت الدراسـه المنهج الوصفى وصممت استقصساء مكسون مـن 60 سـؤال وبلغـت العينـه 383 فـردا مـن العـاملين بمديريـه التربيـه بمحافظه نينوى بجمهورية العراق. و انتهت الدراسـه الى وجود علاقه ارتباط وتأثير معنوى لبعض ابعاد القياده التوزيعيه على ابعاد الارتباط بالعمل. تعليق عام على الدراسات السابقة: يتضح من العرض السابق للدراسات السابقة ندرة الدراسات العربية التي تتاولت هذا المدخل - على حد علم الباحث- بالإضـافة إلى قلة الدراسات التي تتاولت تطبيق هذا المدخل في مدارس التعليم العام، وأن هذه الدراسات توصلت إلى إلى إلى

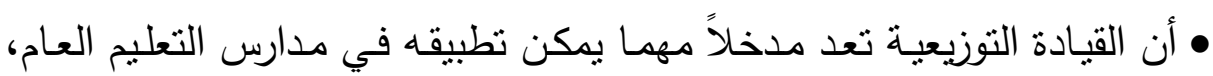
سعياً إلى تطوير الأداء الإداري بالمدرسة.

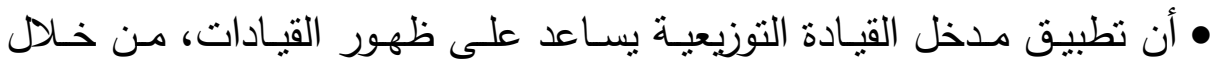

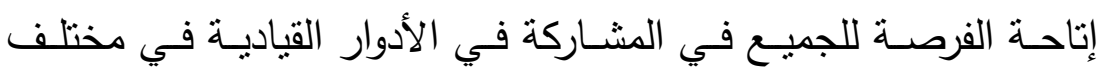
المجالات.

(45) عبدالحكيم ربيع واحمد عز الدين شيت ومني محمد (2016) ـ تأثثر بعض ابعاد القياده

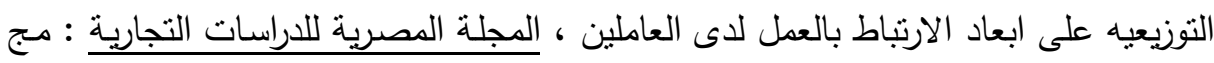
40 40 
•أن تطبيق القيادة التوزيعية بسهم في حل العديد من المشكلات المستعصبة،

$$
\text { التي يصعب حلها. }
$$

•أن تطبيق هذا المدخل يؤكد على أهمية المشاركة، وأهمية العمل التعاوني، لها،

من خلال التأكيد على دور المعلم في العمليات الإدارية.

وقد استفادت الدراسة الحالية من الدراسات السابقة في بعض دل الجوانب منها:

•اختيار المنهج المناسب وهو المنهج الوصفي.

•بناء وتصميم أداة الدراسة الميدانية (الاستبانة).

•بناء الإطار النظري للاراسة الحالية.

ثانيا: إجراءات البحث الميدانية: وفيما يلي توضيحها:

1 - عينة البحث وخصائصها

كانت الخطوة الأولى في عمليـة اختيار العينـة هـى تحديد المجتهـ الأصلي

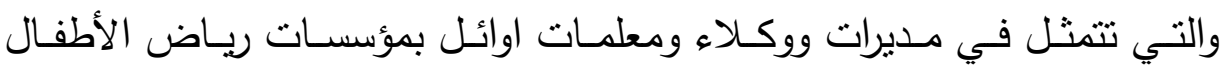
بمحافظة كفر الثيخ بإداراتها المختلفة. ولمـا كان من الصـب دراسـة المجتمـع الأصـلي بأكمله كانت الخطوة الثانيـة اختيار عينة عشوائية من مديرات ووكلاء مؤسسات رياض الأطفال بمحافظة كفر

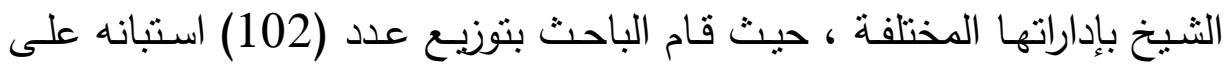

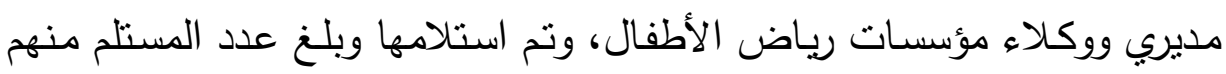

جدول (1) : ملخص عينة الدراسة من المديرين والوكلاء

\begin{tabular}{|c|c|c|c|c|c|c|c|}
\hline باقي & وع المجـــ & بها. مشكوك. & ترد لم & تكتمل لــم. & عينة الـ & الإدارة & p \\
\hline 6 & 6 & 1 & 3 & 2 & 12 & كفر الشيخ & \multirow{5}{*}{ 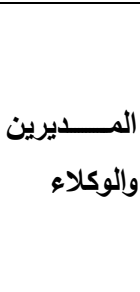 } \\
\hline 4 & 5 & 3 & 1 & 1 & 9 & قلين & \\
\hline 7 & 13 & 5 & 5 & 3 & 20 & سيدي سالم & \\
\hline 5 & 6 & 2 & 2 & 2 & 11 & دسوق & \\
\hline 2 & 3 & 1 & 1 & 1 & 5 & فوة & \\
\hline
\end{tabular}


مجلة الدراسات التربوية والانسانية ـ كلية التربية ـ جامعة دمنهور المجلد الثامن - العدد(3)- لسنة 2016

\begin{tabular}{|c|c|c|c|c|c|c|}
\hline 3 & 6 & 1 & 2 & 3 & 9 & بيلا \\
\hline 2 & 3 & 1 & 1 & 1 & 5 & مطويس \\
\hline 4 & 6 & 3 & 2 & 1 & 10 & الرياض \\
\hline 5 & 7 & 1 & 2 & 4 & 12 & بلطيم \\
\hline 2 & 7 & 3 & 3 & 1 & 9 & الحامول \\
\hline 40 & 62 & & & & 102 & المجموع \\
\hline
\end{tabular}

ويالتالي يصبح الفاقد (62) استمارة أي بنسبة (60.78\%) من جملة (102) استبانة.

2- أداة البحث الميدانية:

توضحها البحث كما يلي:

أ - مبناء أداة الاستبانة

تعد الاستبانة الأداة الأساسية للبحث الميدانى، وتم إعداد الصورة المبدئية

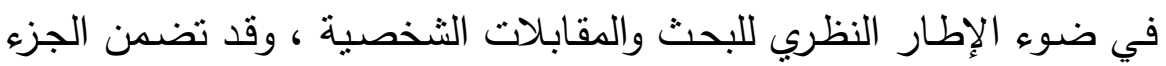

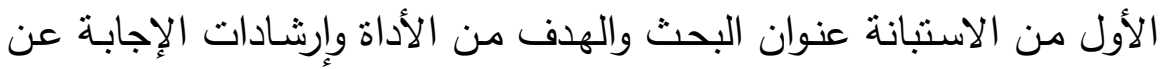

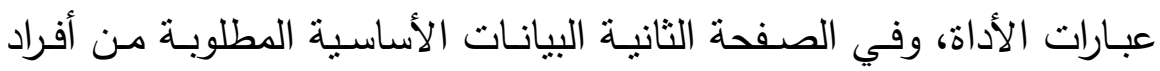

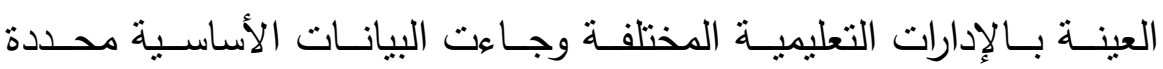
بخصائص أفراد البحث ومتغيراتها، من حيث:

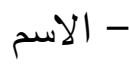
- متغير الوظيفة: ( مدير - وكيل) - متغير المؤهل الدراسي ( أقل من بكالوريوس - بكالوريوس - دبلوم عالي ماجستير - دكتوراه)

- متغير سنوات الخبرة (أقل من 5 سنوات - من 5 سنوات إلى 10 سنوات - منترات من 10 سنوات فأكثر) - في الجزء الثاني اشتملت الاستبانة على (25) عبارة. 


\section{1}

لمـا كان الصـدق في أبسط معانيـه "أن تقيس الأداة مـا وضـعت لقياسـه" تم عرض الاستبانة على (5) من السـادة المحكمين المتخصصين في مجال التربية من أجل التحقق مما يأتي: - مدى مناسبة العبارة للمحور الذي تتنمي إليه. - مدى صلاحية العبارة في قياس ما وضعت لقياسه. - الصياغة العلمية الصحيحة للعبارة.

وبعد إنهاء الاستبانة وعمل التعديالات التي اقترحها السادة المحكمون ؛ حيث تم صياغة بعض العبارات وتعديل أخري ، وحذف أخرى منها واستبدال بعضها ، إلى أن أصبحت الاستبانة في صورتها النهائية (25) (3) عبارة صالحة للتطبيق والتجريب على عينة البحث بعد التحقق من الثبات لها ، وقد طلب من أفراد العينة قراءة كل عبارة ووضـع علامـة (ل ) في أحد الفراغات الموجودة قرين كل عبارة، والتي تعكس بدقة مدى مواجهة المفحوص بتلك العبارات. وقد روعي عند صـياغة عبـارات الاستبانة العديد من الاعتبارات التي تؤكد

عليها المصادر في مناهج البحث منها (4):

$$
\text { 1، أنظر ملحق (1) الصورة الأولية للاسنبانة. }
$$

2، انظر : ديوبولد ب. فان دالين مناهج البحث في التربية وعلم النفس ، (ترجمة) محمد نبيل نوفل

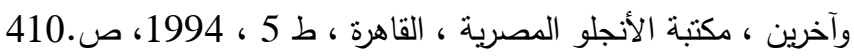

2،George K., Cunnimgham Educational And Psychological Measurement, New York, Macmillan Publishing Company, (1986), P.121..

3،Judith, Bell Doing Your Research Project, London, Open University Press, Third Edition (1999) PP. 118 ، 133. 
- صياغة العبارات بلغة بسيطة واضحة ومركزة تركيزاً تامساً، حتى لا تستعصى على القهم، أو تحتمل أكثر من معنى، ضماناً لصدق الأداة.

- تجنب العبارات المزدوجة والتي تحمل أكثر من فكرة، بحيث تثنتمل كل عبارة على فكرة واحدة لتحقيق الدقة في الاستجابات.

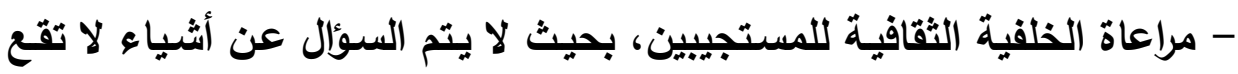
في نطاق خبرتهم، أو تتجاوز حدود معرفتهم.

- الابتعاد قدر الإمكان عن العبارات التي قـ تسبب حرجاً للمستجيبين. - تجنب صياغة العبارات بطريقة توحي بالاستجابة.

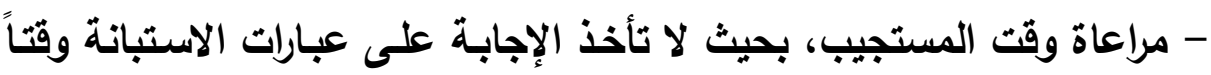

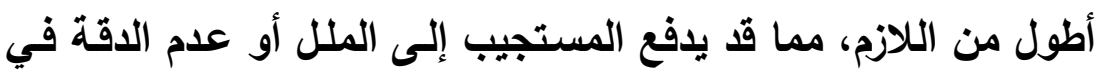
الاستجابة.

Reliability بات الاسبتهاته

يعد الثبات أحد الخصائص السيكومترية اللازم توافرها في أدوات القياس. وهو يمثل مـع الصـدق أساسين يتعـين توافرهمـا في أي أداة حتى تكـون صـالحة

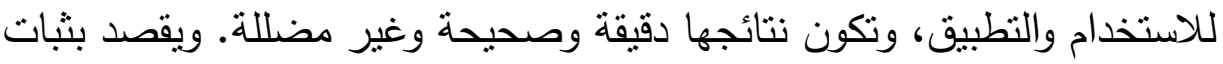

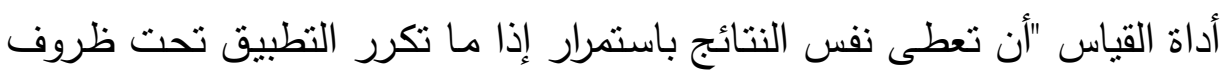

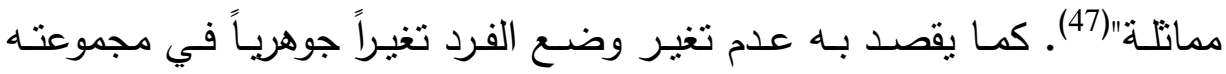
بإعادة تطبيق الأداة أكثر من مرة. وتعتمد طرق قياس ثبات المقياس على فكرة

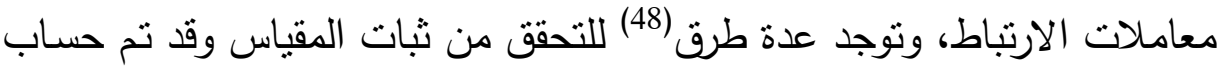

1، ديوبولا ب. فان دالين : مرجع سابق ، ص 41 41.

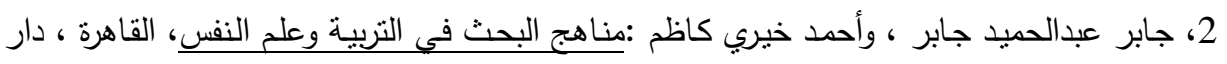

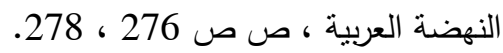


معامل الثبات باستخدام طريقة إعادة تطبيق الاختبار وطريقة معامل ألفا كرونباخ ويتبع كما يلي:

\section{1 - طريقة إعادة تطبيق الاختبار.}

وفى هذه الطريقة يتم اختبار عينـة من الأفراد، ثم إعادة اختبارهم مرة أخرى تحت ظروف منتـابهة بقدر الإمكان، ثم إيجاد معامل الارتباط بين النتائج في الحالتين، فإذا كانـت درجـات الاختبـار فى المرتين ثنابتة أو متقاربـة - أي كان 0.88. معامل الارتباط مساوباً

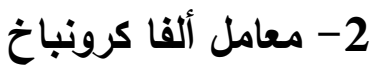

حيث تم التحقق من الثبات باستخدام معامل ألفا كرونباخ ، وبلغت قيمته 0.89.

$$
\text { ج - تطبيق الاستبانة: }
$$

بعد إجراء التعديلات التي أشنار إليها السادة المحكمين تم تطبيق الاستبانة في

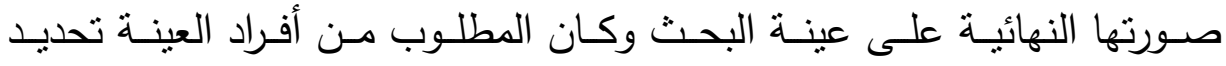
الاستجابة على عبارة الاستبانة وفقا خمسة اختبارات وتم توزبع الاستبانات على عينة البحث بعد التأكد من صدق وثبات الاستبانة تمت إجراءات تطبيق الاستبانة

$$
\text { على أفراد العينة } 0
$$

\section{3- الصورة النهائية للاستبانة:}

تم بناء الاستبانة وفق المحاور السبعة السابق عرضها في (25) عبارة تُعرض على عينة البحث ، حيث يبدون آراءهم وفق أهمية كل عبارة في خمسة مستويات

\begin{tabular}{|c|c|c|c|c|}
\hline قليلة جدا & قليلة & متوسطة & كبيرة & كبيرة جدا \\
\hline 1 & 2 & 3 & 4 & 5 \\
\hline
\end{tabular}
"درجات من درجة الممارسة"

تم اثتقاق أداة البحث من خلال العديد من المصادر يتم إيضاحها فيما يلي: 
* الخبـرة العمليـة Practical Experience وذلك مـن خـلال احتكالك الباحث بالمعلمات والمديرين والموجهات.

* المقابلة Interview حيث قام الباحث بإجراء بعض المقابلات غير المقننة Nonstructural Interviews

التخصصات والدرجات العلمية0 والدراسات السابقة العربية والأجنبية 0 د - الأساليب الإحصائية المستخدمة:

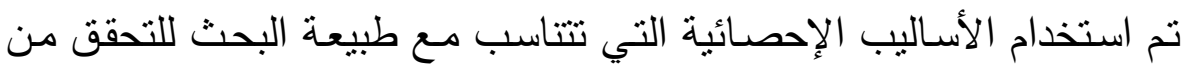

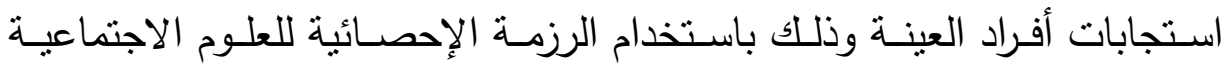

(SPSS)

$$
\text { 1- استخدام التكرارات والنسب المئوية والوزن النسبي0 }
$$

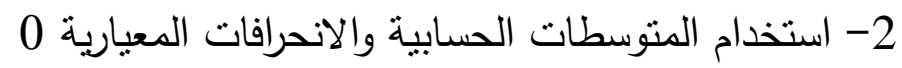

3- استخدام معامل ألفا كرونباخ لثبات الاستبانة 0

4- اختبار حسن المطابقة (أسلوب مربع كا2) Chi Square)) للمقارنة بين التكرارات المشاهدة أو الملاحظة والتكرارات المتوقعة وذلك لبيان دلالة الفروق بين

استجابات أفراد العينة على كل عبارة ، حيث درجة تحققها في الواقع الفعلي 0 ثالثا: نتائج البحث الميدانية: بعد إجراء المعالجـة الإحصائية، ثم رصد النتائج في صورة جداول إحصـائية وتحليلها وتفسيره على النحو التالي: - مـا واقـع تطبيتق القيـادة التوزيعيـة بمؤسسـات ريـاض الأطفال في ضوه بعض الاتجاهات المعاصرة ؟ ولإجابـة عن هذا السؤال قام الباحث بعرض لنتائج وآراء أفراد العينـة على لـى

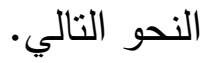


متطلبات تطبيق القيادة التوزيعية بمؤسسات رياض الأطفال فى ضوء بعض الاتجاهات د. أحمد محمد هميسة

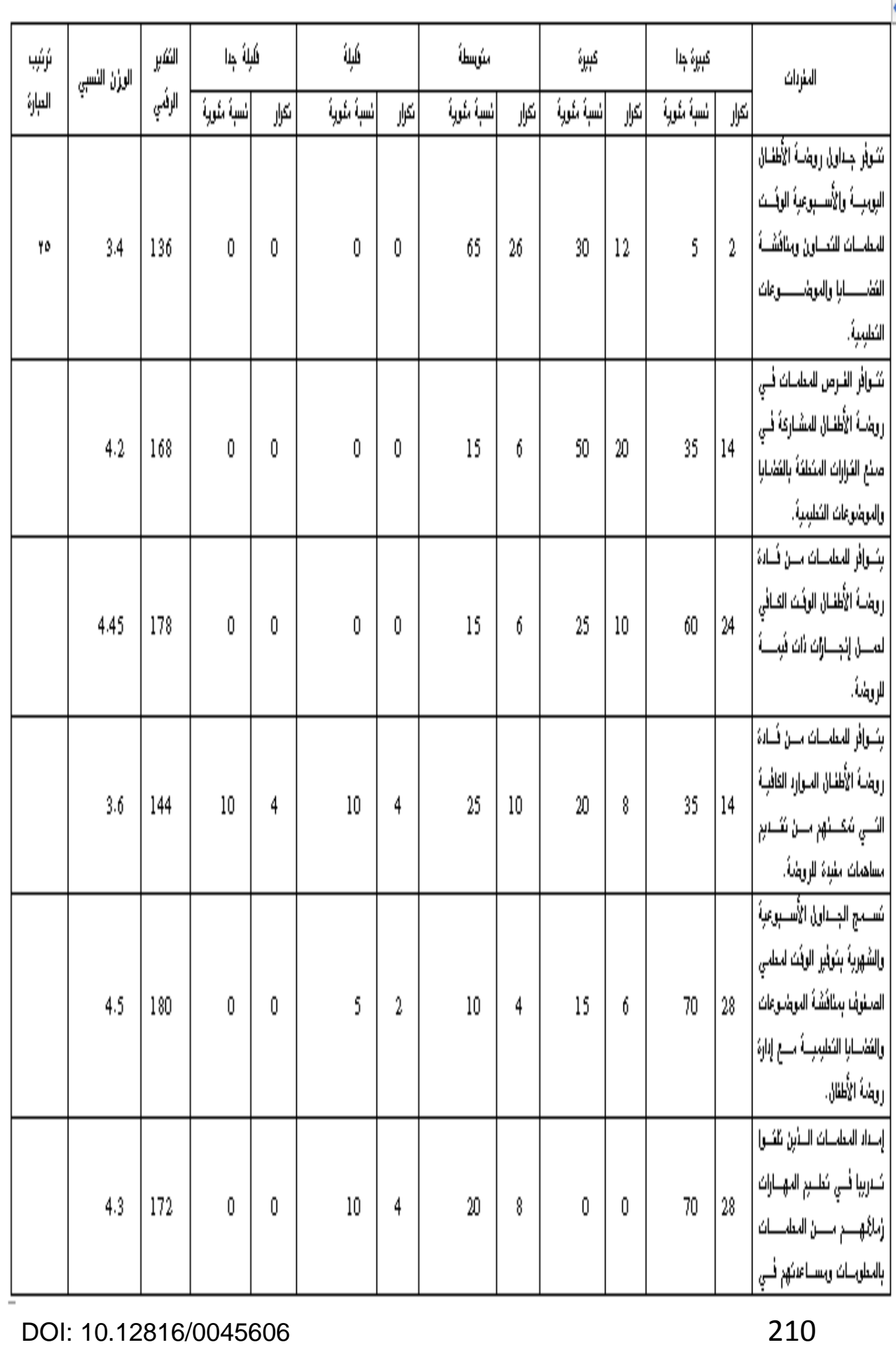


مجلة الدراسات التريوية والانسانية ـ كلية التربية . جامعة دمنهور . المجلد الثامن - العدد(3)- لسنة 2016

\begin{tabular}{|c|c|c|c|c|c|c|c|c|c|c|c|c|c|}
\hline \multirow{2}{*}{ البرائ } & \multirow{2}{*}{ الوزان النسب ب } & \multirow{2}{*}{ 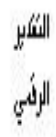 } & \multicolumn{2}{|c|}{ كلكلاً بـا } & \multicolumn{2}{|l|}{ كلكلبا } & \multicolumn{2}{|l|}{ ím } & \multicolumn{2}{|l|}{ كאب } & \multicolumn{2}{|l|}{ كئرئها } & \multirow{2}{*}{ الينزاكا } \\
\hline & & & 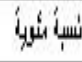 & ائزلر & 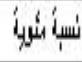 & | & 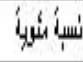 & أثرال & 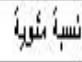 & |ثرار & سبة سُشياً & |ثرالر & \\
\hline & & & & & & & & & & & & & 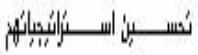 \\
\hline & 4.45 & 178 & 0 & 0 & 0 & 0 & 15 & 6 & 25 & 10 & 60 & 24 & 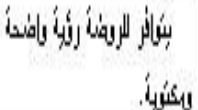 \\
\hline & 4.45 & 178 & 0 & 0 & 0 & 0 & 15 & 6 & 25 & 10 & 60 & 24 & 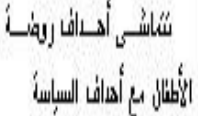 \\
\hline & 4.45 & 178 & 0 & 0 & 0 & 0 & 15 & 6 & 25 & 10 & 60 & 24 & 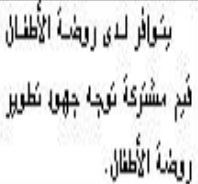 \\
\hline & 5 & 200 & 0 & 0 & 0 & 0 & 0 & 0 & 0 & 0 & 100 & 40 & 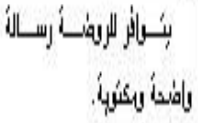 \\
\hline & 4.35 & 174 & 0 & 0 & 0 & 0 & 10 & 4 & 45 & 18 & 45 & 18 & 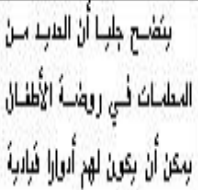 \\
\hline & 4.85 & 194 & 0 & 0 & 0 & 0 & 0 & 0 & 15 & 6 & 85 & 34 & 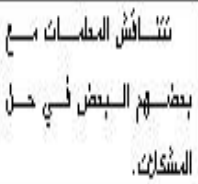 \\
\hline & 4.7 & 188 & 0 & 0 & 0 & 0 & 5 & 2 & 20 & 8 & 75 & 30 & 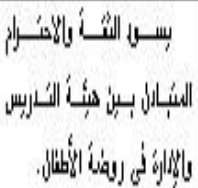 \\
\hline & 3.95 & 158 & 0 & 0 & 5 & 2 & 15 & 6 & 60 & 24 & 20 & 8 & 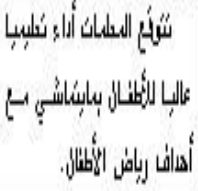 \\
\hline & 4.5 & 180 & 0 & 0 & 0 & 0 & 10 & 4 & 30 & 12 & 60 & 24 & 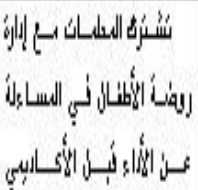 \\
\hline
\end{tabular}


متطلبات تطبيق القيادة التوزيعية بمؤسسات رياض الأطفال فى ضوء بعض الاتجاهات د. أحمد محمد هميسة

\begin{tabular}{|c|c|c|c|c|c|c|c|c|c|c|c|c|c|}
\hline \multirow{2}{*}{ رلرَّبّا } & \multirow{2}{*}{ الوزلن المُسبي } & \multirow{2}{*}{ الالَّبِ } & \multicolumn{2}{|c|}{ لكللاً بـا } & \multicolumn{2}{|l|}{ كلكلباً } & \multicolumn{2}{|l|}{ 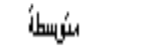 } & \multicolumn{2}{|l|}{ كئِ } & \multicolumn{2}{|l|}{ 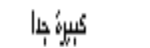 } & \multirow{2}{*}{ الثنراك } \\
\hline & & & نسبا، سُرياً & كيَّرار & 'سبا، سُرياً & تئرار & 'سباً، شُبرية & كئرال & 'سباً شُشياً & كَّرا & سباً سُرياً & |ثَلر & \\
\hline & & & & & & & & & & & & & الرأغنالان. \\
\hline & 3.65 & 146 & 0 & 0 & 15 & 6 & 15 & 6 & 60 & 24 & 10 & 4 & 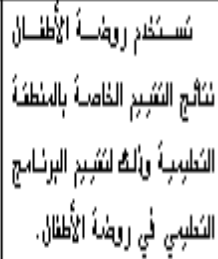 \\
\hline & 4.1 & 164 & 0 & 0 & 10 & 4 & 20 & 8 & 20 & 8 & 50 & 20 & 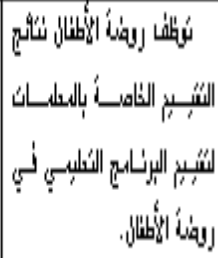 \\
\hline & 4.15 & 166 & 0 & 0 & 0 & 0 & 20 & 8 & 45 & 18 & 35 & 14 & 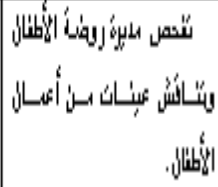 \\
\hline & 4.4 & 176 & 0 & 0 & 0 & 0 & 0 & 0 & 60 & 24 & 40 & 16 & 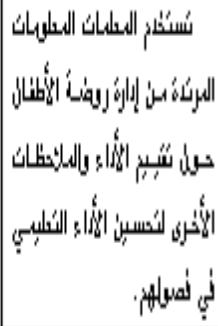 \\
\hline & 3.5 & 140 & 0 & 0 & 20 & 8 & 35 & 14 & 20 & 8 & 25 & 10 & 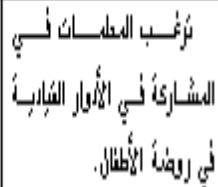 \\
\hline & 4.2 & 168 & 0 & 0 & 0 & 0 & 20 & 8 & 40 & 16 & 40 & 16 & 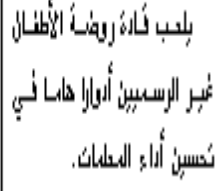 \\
\hline & 3.8 & 152 & 0 & 0 & 5 & 2 & 45 & 18 & 15 & 6 & 35 & 14 & 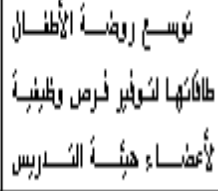 \\
\hline
\end{tabular}

DOI: 10.12816/0045606 
مجلة الدراسات التريوية والانسانية ـ كلية التربية . جامعة دمنهور . المجلد الثامن - العدد(3)- لسنة 2016

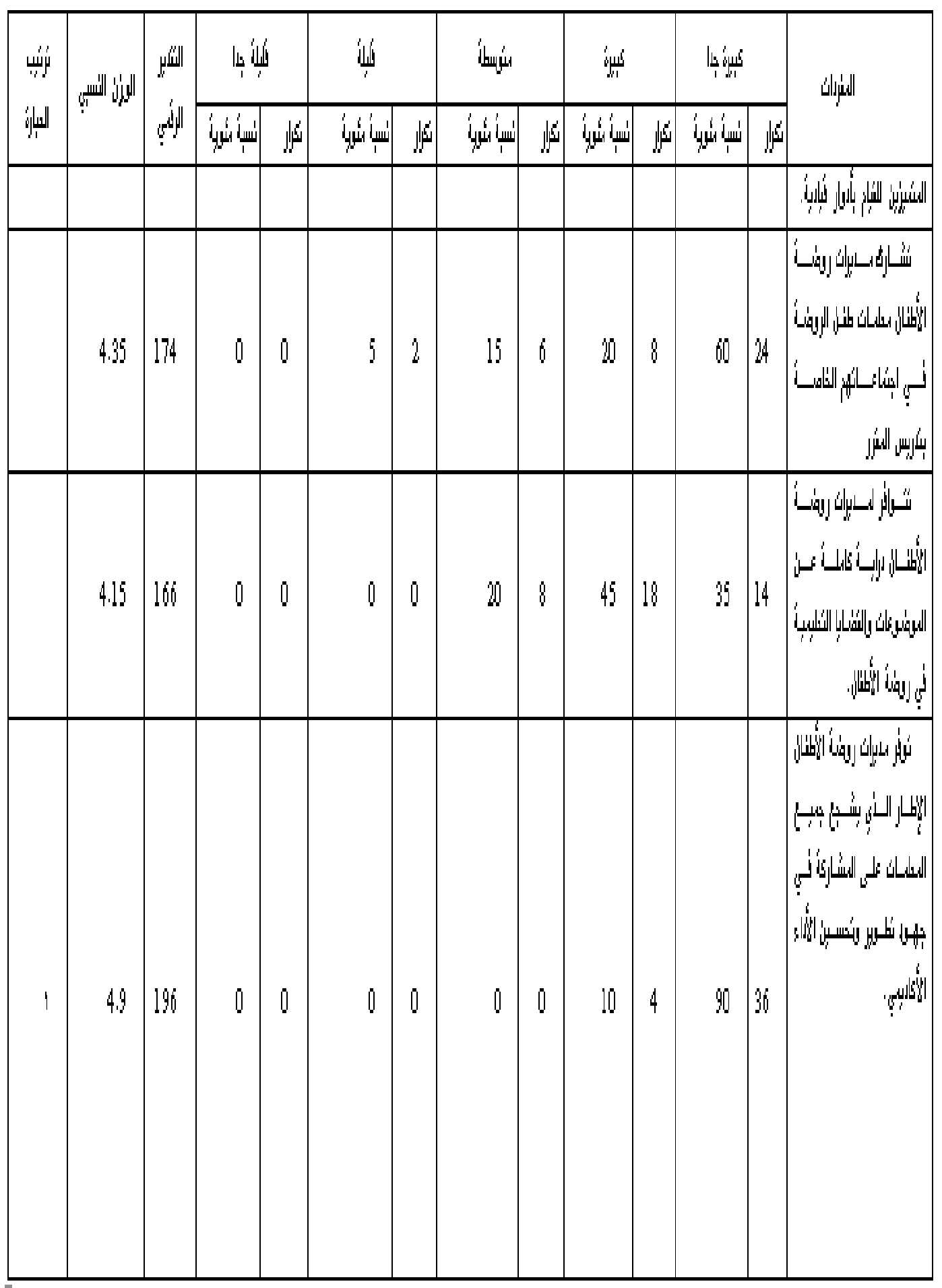




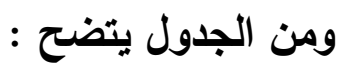

أ- جاءت استجابات أفراد العينـة كمـا هو بالجدول السـابق حول " عبـارات

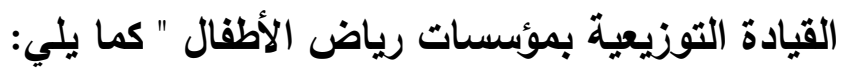

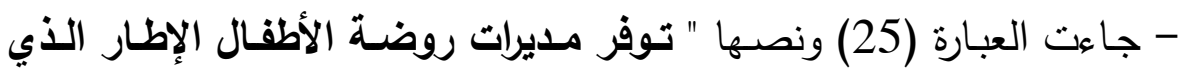

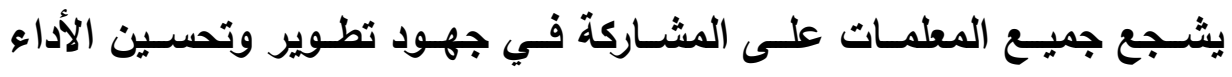

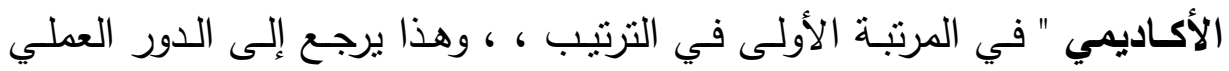
لمديرات الروضة في الاهتمام بالتتمية المهنية للمعلمات.

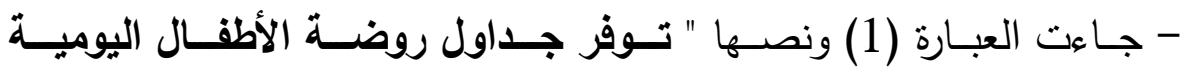
والأسبوعية الوقت للمعلمات للتعاون ومناقثة القضايا والموضوعات التعليمية " في المرتبة الأخيرة في الترتيب، وهذا يرجع إلى أن العدل يحتاج لوقت أطول وازدحام اليوم الدراسي.

وربما يرجع ذلك إلا اعتقاد مديري المدارس ومشرفي الإدارة المدرسية بأن الدور

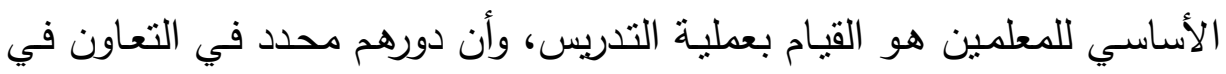
إدارة الددرسة، ويقتصر فقط على قيامهم بما يتم تكليفهم به من أعمال، وإن كانوا

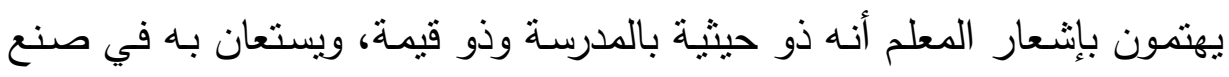

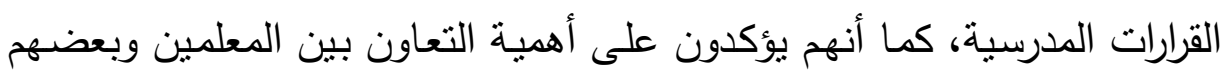
البعض خاصة داخل نفس التخصص.

ولعل من مجمل القول أن يؤكد الباحث على ضرورة تدريب مديري مؤسسات

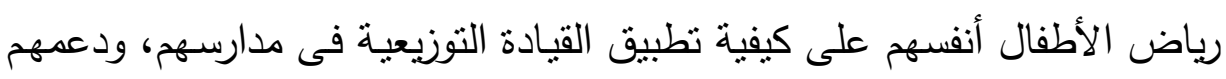

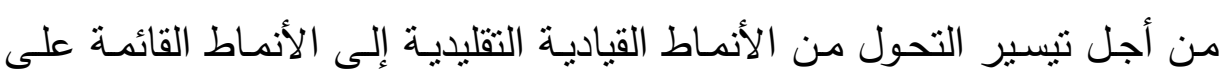

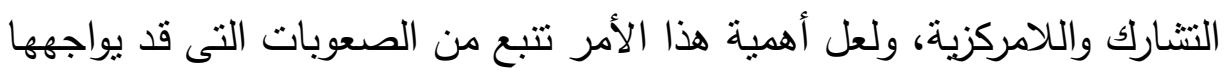

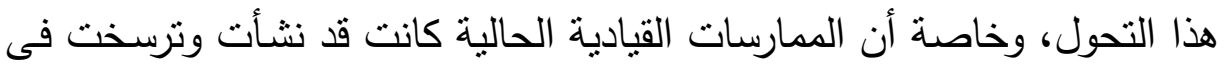
ظل نظام تربوى شديد المركزية امتد عبر عقود طويلة من الزمن، وسوف يتطلب 
تغييره جهودا مضنية من صانعى السياسة التربوية وممارسى القيادة التربوية على جميع المستويات. التوصيات: في ضوء النتائج المستخلصة من الاراسة الحالية فإن الدراسة توصى بما يلي: •ضرورة تدريب مديري مؤسسات رياض الأطفال على استخدام مدخل القيادة

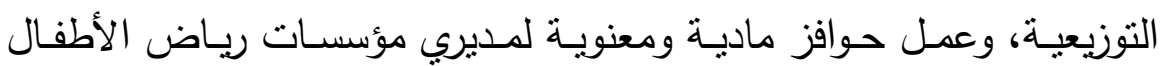
الذين يطبقون هذا المدخل في مدارسهم وفقا لمعايير محددة. • تدريب المعلمات على المهارات القيادية المختلفة التي تجعلهم مؤهلين لمعاونة مديري مؤسسات رياض الأطفال في تطبيق مدخل القيادة التوزيعية. •تخفيف العبء التشريسي عن المعلمات حتى يستطيعوا ممارسة الأدوار القيادية

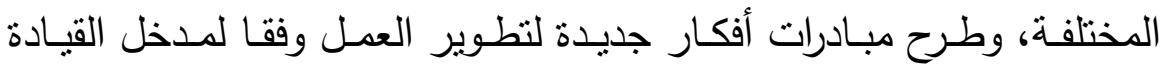
التوزيعية. • نشر الثقافة التي تؤدي تطبيق مدخل القيادة التوزيعية بين المعلمات والمديرين بمؤسسات رياض الأطفال.

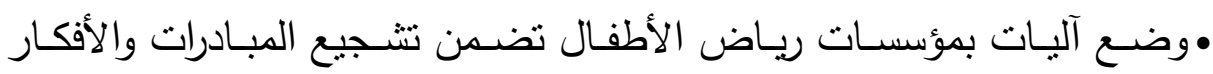

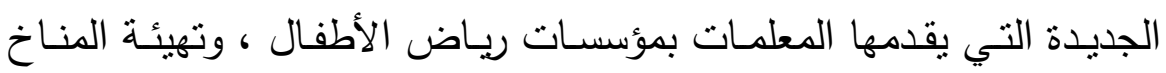
الذي يسمح بذلك، سواء أكانت هذه المبادرات فردية أو جماعية.

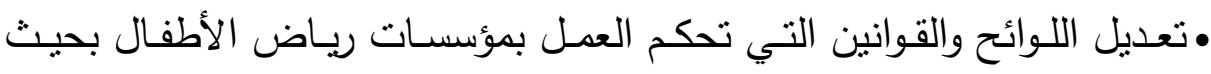

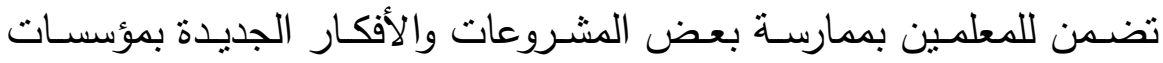

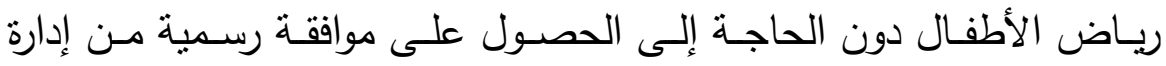
مؤسسات رياض الأطفال ، وإعطاء المعلمين أدوار أساسية في تسيير شئون

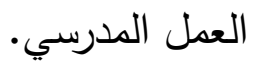


منطبات تطبيق القيادة التوزيعية بمؤسسات رياض الأطفال فى ضوء بعض الاتجاهات ـ. أحمد محمد هميسة

• عمـل متابعـات مستمرة لمدى تطبيـق مدخل القيـادة التوزبعيـة داخل المـدارس، وتحديـد نقـاط الضـعف التي تواجـه عمليـة التطبيـق والعمـل على علاجهـا

$$
\text { والتخلب عليها. }
$$

\section{بحوث مقترحة}

انطلاقا من أهمية موضوع القيادة التوزيعية ، وفي ضوء ما ثوصل إلبه البحث مـن خلاصـات يوصـي الباحـث بـإجراء عدد مـن البحـوث الميدانيـة عن القبـادة التوزبعية في المجالات التالية: •واقع ممارسة القيادة التوزيعية في مدارس التعليم العام كما يراها مديرو المدارس والمعلمون. • معوقـات تطبيـق القبـادة التوزيعيـة بمـدارس التعلـيم العـام كمـا يـدركها مـديرو

$$
\text { المدارس. }
$$

• القيادة التوزيعية وعلاقتها بالنمط القيادي السائد لدى مديري الروضات. • دور القيادة التوزيعية في تفعيل الممارسات الإدارية بمؤسسات رياض الأطفال. • متطلبـات تطبيـق القيـادة التوزيعيـة في مـارس التعليم العـام مـن وجهـة نظـر

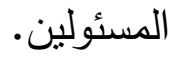

•واقـع قيـادة المعلمـات في ضـوءء مفهـوم القيـادة التوزيعيـة: دراسـة ميدانيـة بمؤسسات رباض الأطفال.

•درجة تقدير مديري المدارس لأهمية تطبيق القيادة التوزيعية في مدارسهم. •درجة امتلاك المديرين والمعلمين بمؤسسات رياض الأطفال للمهارات اللازمـة لتطبيق القيادة التوزبعية. 
مجلة الدراسات التربوية والانسانية ـ كلية التربية ـ جامعة دمنهور المجلد الثامن - العدد(3)- لسنة 2016 


\section{قائمة المراجع}

أولاً" المراجيع العريبة:

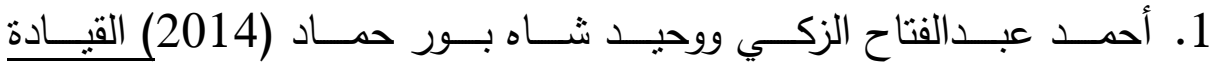

التوزيعية :أسسها ومنطلبات تطبيقها في مدارس التعليم العام بمصر،

دراسة تحليلية، القاهرة ، دار الفكر العربى.

2. امجد محمود درادكة والسيد محمد جابر ظافري (2014). درجهـ ممارسهـ

القياده التوزيعيه لدى مديرى مدارس التعليم العام لدى مدينه الطائف ،

مجلة البحث العلمى في التربية ، العدد (15).

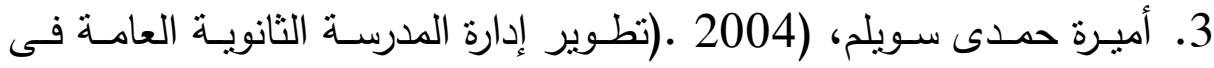

مصر فى ضوء منظلبات القرن الحادى والعشرين، رسالة ماجستير

غير منشورة، كلية التربية جامعة الزقازيق.

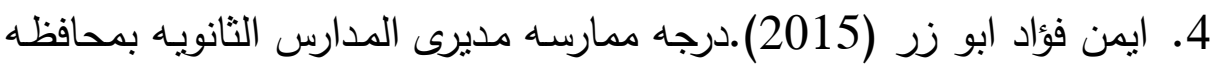
غزه للقياده التوزيعيـه وعلاقتها بمستوى الفاعليه الذاتيـه للمعلمين".

رسالة ماجستير غير منثورة ، الجامعة الاسلامية بغزة.

5. ايناس محمد اسماعيل وعباس عبدمهدي (2015). القياده الموزعه لمديرى لئه

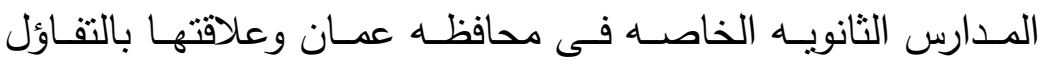
الاكاديمى للمعلمين من وجهه نظرهم ، رسالة ماجستير غير منشورة ، كلية العلوم التربوية : جامعة الثرق الأوسط. الاردن.

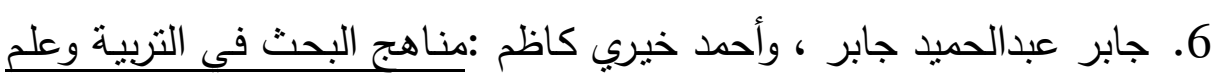

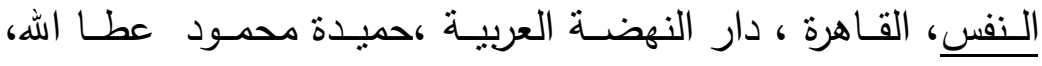

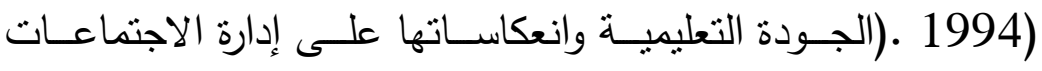

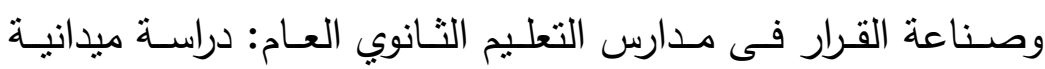
بمحافظة الدقهلية، رسالة ماجستير غير منشورة، كلية التربية جامعة الفية

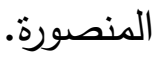


7. ديوبولد ب. فان دالين مناهج البحث في التربية وعلم النفس ، (ترجمة) محمد

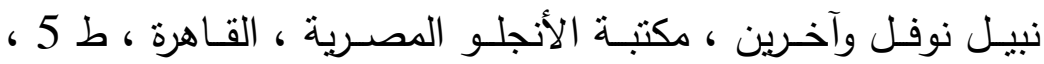

8. رافدة عمر الحريري، القيادات الإداريـة لمدارس المستقبل في ضوء الجودة

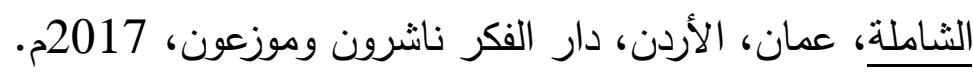
9. سالم سعيد القحطاني، القيادة الإدارية التحول نحو نموذج القية القيادي العالمي، مكتبة الملك فهذ الوطنية، ط2، الرياض، 1429هـ، 2008.

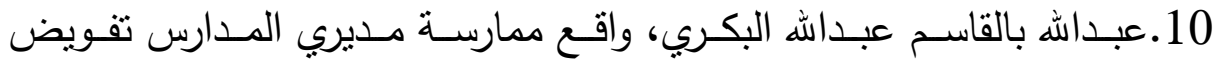
الصلاحيات للمعلمين وعلاقته بتحقيق فعالية المدرسة دراسة ميدانية

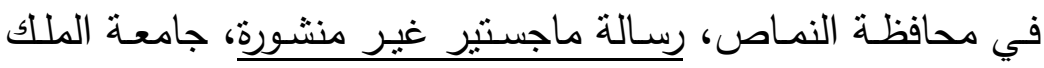

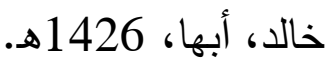

11 1.عبدالحكيم ربيع واحمد عز الدين شيت ومني محمد (2016) ـ تأثير بعض اهض

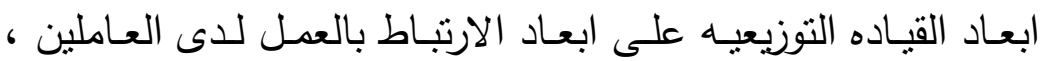

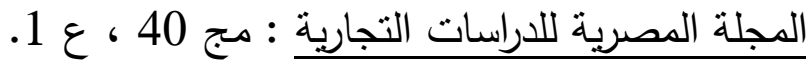
12.على سويلم حسن الصغير ، واقع تفويض الصلاحيات لاى مديري المدارس الثانوية بمدينة الرياض، رسالة ماجستير غير منشورة، كلية التربية، جامعة الملك سعود، الرياض، 14277هـ.

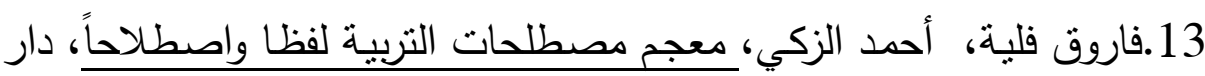

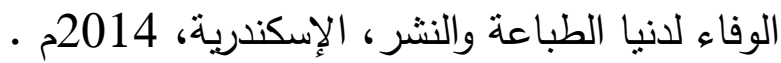
14.محمد جودة التهامى، (2010). أنماط الإدارة التعليمية المتبعة فى بعض الإسل الدول وانعكاساتها على إدارة مرحلة التعليم الابتدائى: دراسـة تحليلية

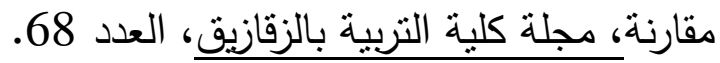
15.المنجد في اللغة والاعلام ، ط34 ، بيروت ، المكتبة الشرقية ، 1994. 
متطلبات تطبيق القيادة التوزيعية بمؤسسات رياض الأطفال فى ضوء بعض الاتجاهات د. أحمد محمد هميسة

16 ـنىى مؤتمن ،، قبادة التغيير في المؤسسة التربوية، بحث ترقية محكم- وزارة التربية الاردنية ، 2014 .

17.نادية محمد عبدالمنعم، وعزة جله مصطفى، (2008 )الإدارة المدرسية

المعاصـرة فيى ظـل المتغيـرات العالميـة، القـاهرة: المجموعـة العربيـة

$$
\text { للتدربب والنشر - }
$$

18.نـاعم أحمـد سـلطان العمـري، واقع مشـاركة معلمي المرحلـة الثانويـة بمدينـة الرياض في عملية اتخاذ القرارات المدرسية دراسـة ميدانيـة في مدينة الرياض، رسـالة ماجستير غير منشورة، كليـة التربية، جامعـة الملك

$$
\text { سعود، الرياض، 2002م. }
$$

19.وزارة التربية والتعليم:التمية المهنية لمديري المدارس، 2017.

20.يوسف عبدالمعطى مصطفى، (2002). أسـلوب القيادة التحويليـة كمدخل

لتحسين أداء مـدير المدرسـة فى مصـر، التربيـة، العدد 7، الجمعيـة

المصرية للتربية المقارنة والإدارة التعليمية.

21.يوسـف عبدالمعطي مصطفى:اسـلوب القيـادة التحويليـة لتحسـين اداء مـدير

المدرسـة في مصسر ، الجمعيـة المصـريـة للتربيـة المقارنـة والادارة

التعليميـة، العـدد السـابع، السـنة الخامسـة، مـن ص(139-202) ،

.2002

ثانباً: المراجع الأجنبة:

22. Arrowsmith, Trevor (2007), Distributed Leadership in Secondary Schools in England: The Impact on the Role of The Headteachers and Other Issues, management in Education, Vol, 21.

23. Elmore, R. Building a New structure for school leadership. Washington, DC: the Albert shanker Institute, 2000. 
مجلة الدراسات التربوية والانسانية ـ كلية التربية ـ جامعة دمنهور المجلد الثامن - العدد(3)- لسنة 2016

24. George K. Cunnimgham Educational And Psychological Measurement, New York, Macmillan Publishing Company, (1986) .

25. Hammad, W. \& Norris, N. (2009). Centralised Control: A Barrier to Shared Decision-making in Egyptian Secondary Schools. International Studies in Educational Administration, 37(2): 60-73.

26. Hammad, W. (2010). Teachers' Perceptions of School Culture as a Barrier to Shared Decision-making (SDM) in Egypt's Secondary Schools. COMPARE, 40(1): 97-110.

27. Harris, A. (2003). Teacher Leadership as Distributed Leadership: heresy, fantasy or possibility? School Leadership \& Management, 23(3): 313-324.

28. Harris, A. (2004). Distributed Leadership and School Improvement: Leading or Misleading? Educational Management Administration \& Leadership, 32(1): 11-24.

29. Harris, A. (2005). Distributed Leadership. In B. Davies (Ed.), The essentials of school leadership (pp. 160172). London: Paul Chapman.

30. Harris, Alma (2012) Distributed Leadership in Schools, Leading or Misleading? Paper presented at the British Educational Leadership Management and Administration Society Conference, Birmingham, England, September 2002 , P4.

31. Judith Bell, Doing Your Research Project, London, Open University Press, Third Edition (1999) PP. 118 ، 133.

32. Leathwood, k.et al (2007) Distributed leadership to make schools smarter: taking the ego out of the system , leadishp and policy in schools, 6 (1), pp. 37. 


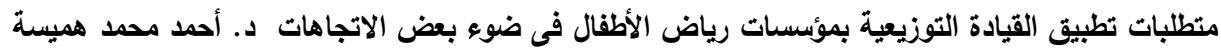

33. Leathwood, Kenneth \& Jantzi, Doris (2008), Distributed Leadership and Student Engagement in schools, paper presented at the Annual meeting of the American Educational Research Association, San Diego CA, April 13-17, p.123.

34. Malen, B., Ogawa, R, \& Kranz, J, (1990). Site-Based Management: Unfulfilled Promises, The School Administrator 47(2): 30-59.

35. Martinez, Cecilia et al. (2005) leadership alignment the challenges of distributed leadership, paper presented at the Annual Meeting of the American Education Research Association Montrel.

36. Mengtian (2011). Distributed leadership and Teachers' self-efficacy: The case studies of three chinese schools in shanghai, Master's thesis, November, Department of education , Institute of educational leadership , University of jyväskylä.

37. Muijs, D. and Harris, A (2007). Teacher Leadership in (In)action. Three Case Studies of Contrasting Schools, Educational Management Administration \& Leadership, 35 (1): 111-1344.

38. Wallace, M. (2001). Sharing Leadership of Schools through Teamwork: A. Justifiable Risk? Educational Management \& Administration, 29( 2): 153 -167.

39. Warfield, C. A Social Network Analysis of Distributed Leadership in Schools, Unpublished doctoral dissertation, University of Pennsylvania, Philadelphia, USA, 2009. 
مجلة الدراسات التربوية والانسانية ـ كلية التربية ـ جامعة دمنهور المجلد الثامن - العدد(3)- لسنة 2016 